\title{
The impact of Free Trade Agreements on Information Technology based business
}

AHRC Research Centre for Studies in Intellectual Property and Technology

Law, University of Edinburgh

Abbe Brown

Andres Guadamuz

Jordan Hatcher 
$1.0 \quad$ EXECUTIVE SUMMARY .......................................................................................................4

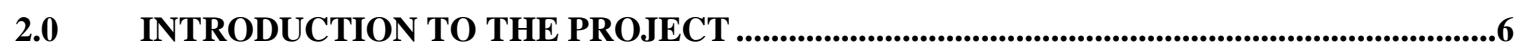

3.0 OVERVIEW OF FREE TRADE AGREEMENTS .........................................................8

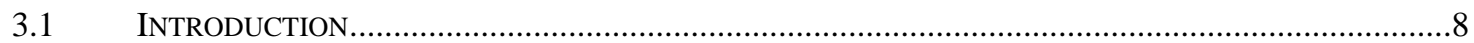

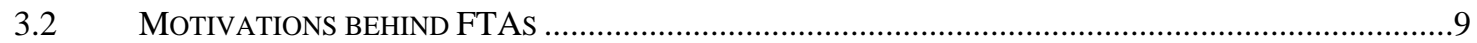

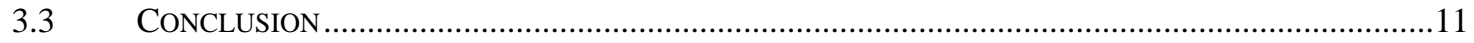

4.0 LEGAL FRAMEWORK OF FTAS ……..................................................................................11

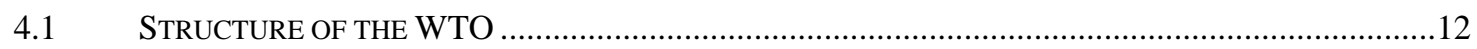

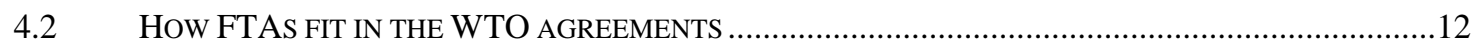

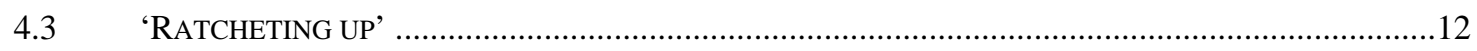

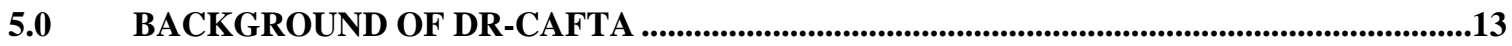

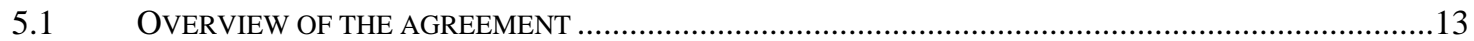

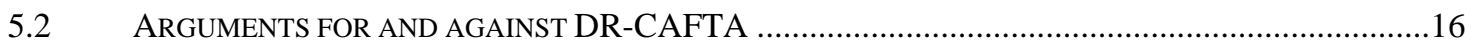

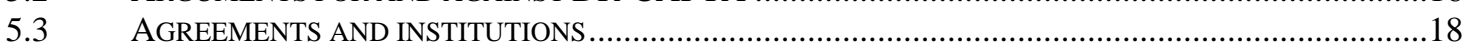

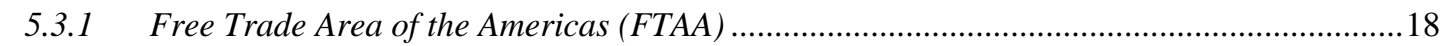

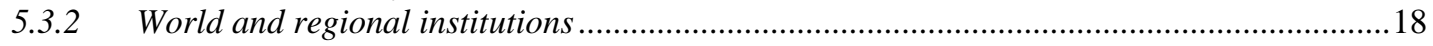

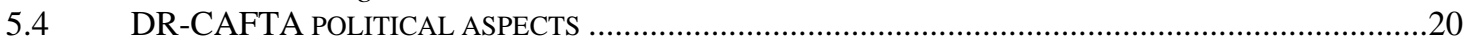

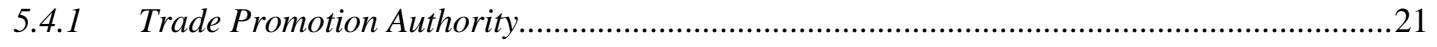

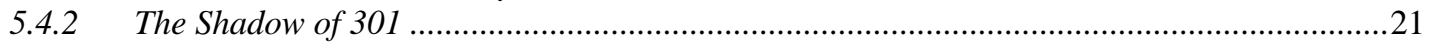

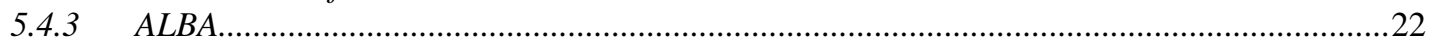

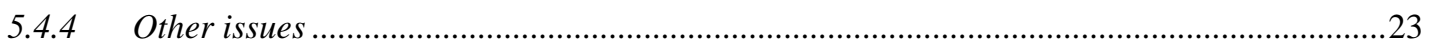

6.0 IMPACT FOR IT-BASED BUSINESS …...............................................................................23

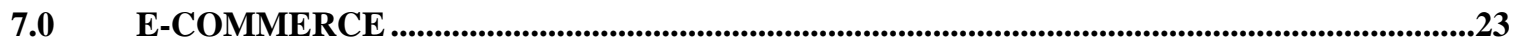

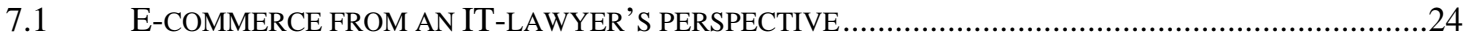

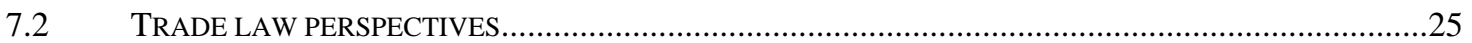

OTHER ASPECTS OF E-COMMERCE IN LATIN AMERICA ……...........................................28

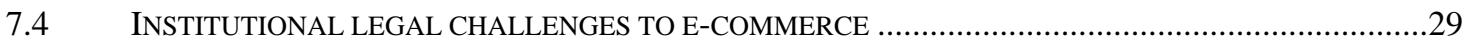

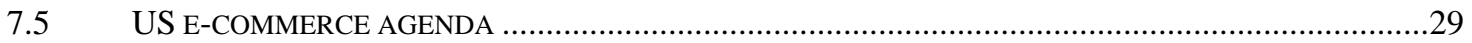

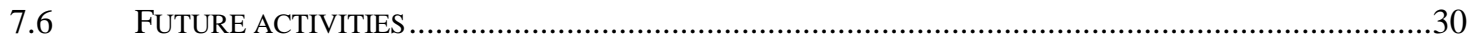

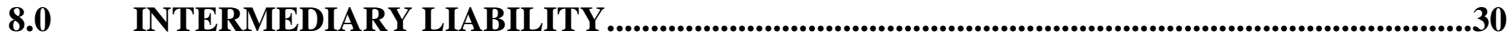

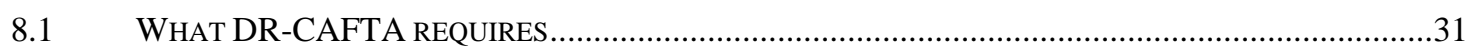

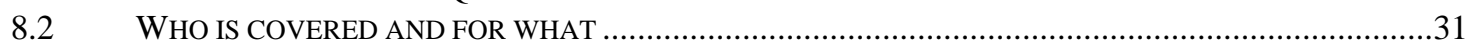

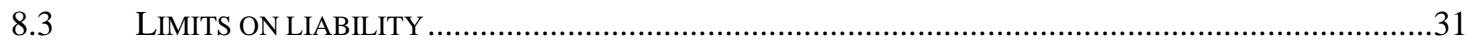

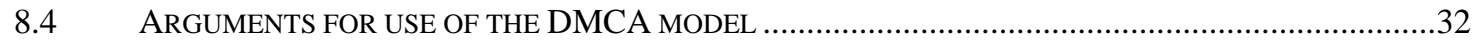

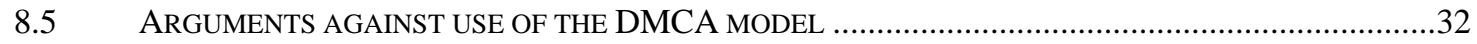

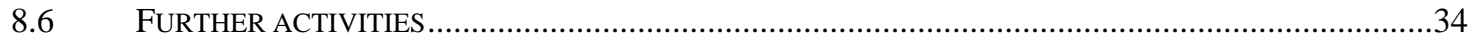

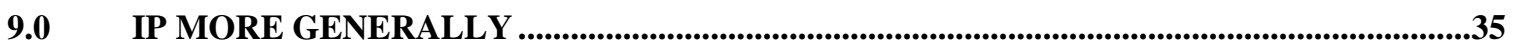

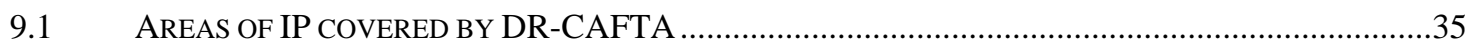

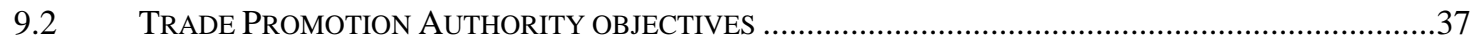

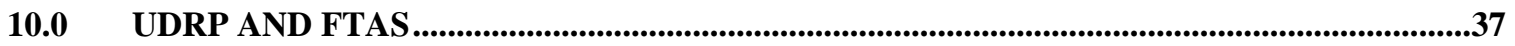

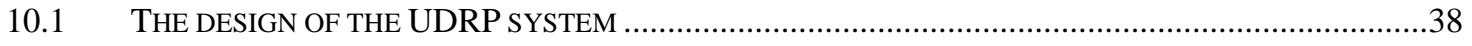

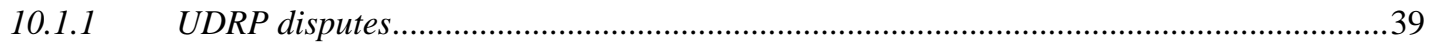

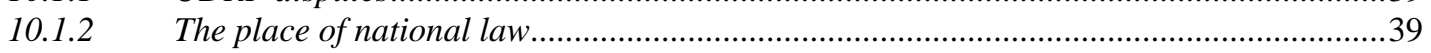

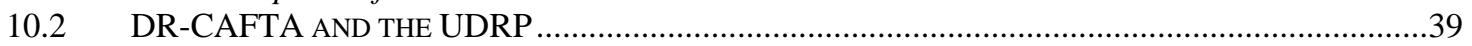

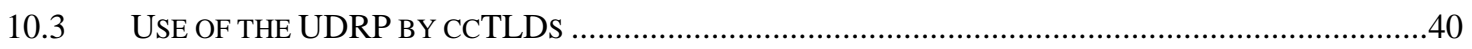

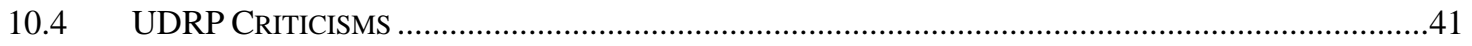




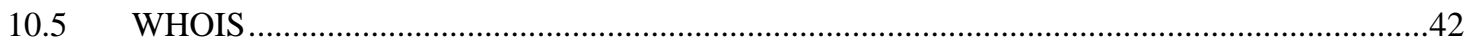

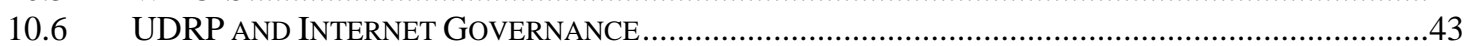

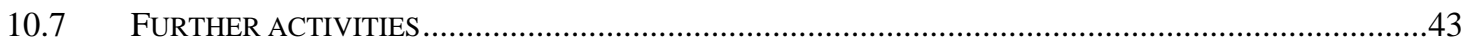

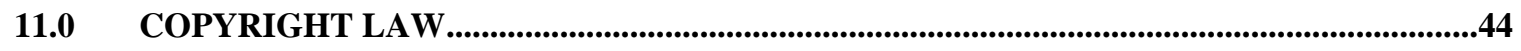

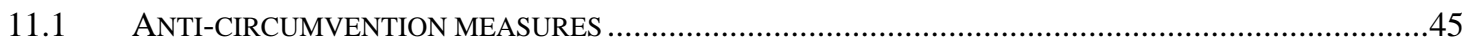

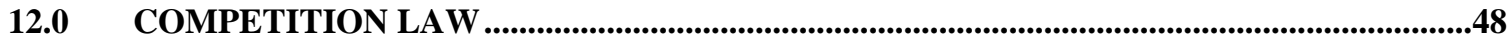

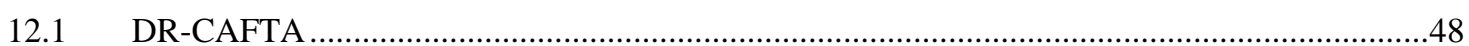

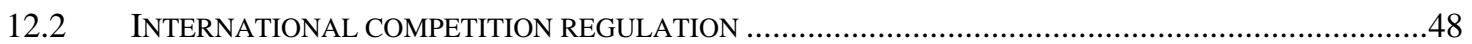

12.3 CENTRAL AMERICAN COMPETITION REGULATION ..............................................................48

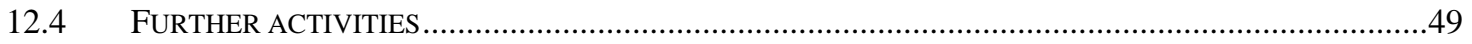

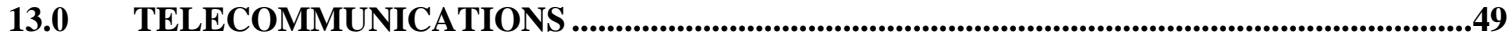

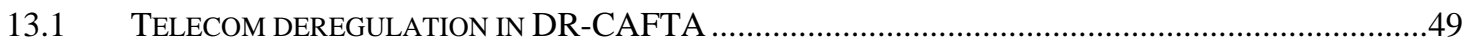

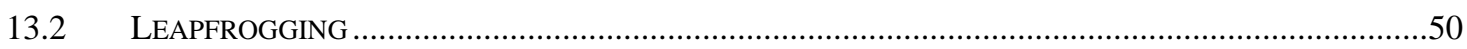

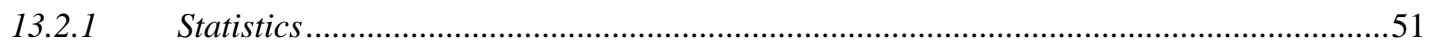

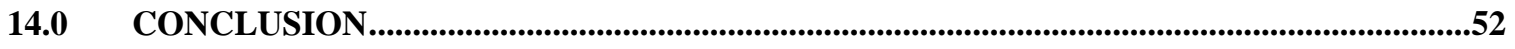

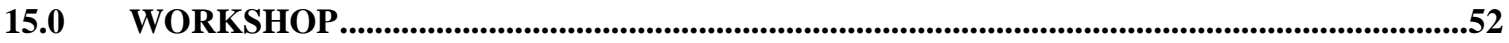




\subsection{Executive Summary}

This report considers the Dominican Republic - Central America Free Trade Agreement (DR-CAFTA) ${ }^{1}$ and its impact on Information Technology (IT) based businesses. The report summarises the factual background to, and contents of, the agreement, and then reviews those parts of the agreement (or omissions from the agreement) that are relevant to the IT field. IT is of interest both because of its potential importance as a contributor to business (and social) growth, but also because of the lesser international roles accorded to it in comparison with its sister, intellectual property (IP). The IT-related provisions of DR-CAFTA reflect international IT (and IP) controversies. But DR-CAFTA also raises questions of the place of agreements between states, their legal validity and their impact upon international relationships and global development.

The primary objective of this project was to explore the extent to which DR-CAFTA impacts upon IT based businesses; the implications of this; to assess how much these issues, and associated economic and legal questions, had been addressed; and to lay the foundations for further legal and interdisciplinary work. We have not, at this stage, explored all the issues covered and not covered in DR-CAFTA, and arising in respect of other agreements of this nature. Rather, we have sought to introduce the issues, provide preliminary comment, and provide a list of resources for further study. We hope that this will be helpful to those coming to the project from a variety of backgrounds, including different legal specialities.

We have concluded that there are important issues to be developed regarding all free trade agreements and IT. These issues are highlighted in the following sections. In terms of immediate further work, we propose investigating the present and future impact of UDRP provisions in DR-CAFTA countries, and liability of Internet Service Providers (ISPs). We believe that these can raise important questions combining IT, e-commerce, IP, trade, human rights and competition issues; both for DR-CAFTA countries and those contemplating their own agreements. We also consider that there is a need for international and interdisciplinary collaboration for this work to be done, including through empirical research with ISPs and domain name owners. We propose holding an international meeting of experts. We are also considering publishing this report in Spanish.

Progress has been shared on the project blog, http://freetrade.opencontentlaw.org throughout, and we have been delighted with the interest expressed from a variety of corners. We anticipate this report being transformed into a wiki and for further contributions to be developed via web-based. We hope to maintain the project's momentum through the wiki, and details of this will be posted on the blog.

\footnotetext{
${ }^{1}$ Central America-Dominican Republic-United States Free Trade Agreement (August 5, 2004):

$<$ http://www.ustr.gov/Trade_Agreements/Bilateral/CAFTA/CAFTA-DR_Final_Texts/Section_Index.html $>$
} 
This project was one of the final activities of Phase 1 of the AHRC Research Centre for Studies in Intellectual Property and Technology Law at the University of Edinburgh (AHRC Research Centre). We are grateful to the AHRC for their support, and look forward to pursuing parts of this work in Phase 2. 


\subsection{Introduction to the project}

Free trade agreements (FTAs) have long been controversial; also referred to as regional trade agreements (RTAs), it is increasingly common for agreements to be entered into between countries and regions which are geographically remote (e.g. US-Australia, USJordan). A free trade agreement is an arrangement between 2 or more countries to reduce trade barriers between the parties. Within the literature, an FTA is a kind of RTA, which is the broader term used to describe both FTAs and customs unions. The IP aspects of free trade agreements have received significant academic attention, with concerns that more powerful countries require others to refuse to permit compulsory licensing, or exceptions to IP rights, notwithstanding that these are permitted by TRIPS and related instruments. These are often called TRIPS PLUS obligations.

There is also, however, cause for concern in respect of IT, and the restrictions imposed by FTAs on the ability of countries, particularly in developing areas, to take full advantage of the opportunity and flexibility offered by information technology to develop new and competitive economies. As mentioned, IP and its relationship with FTAs is an area of considerable academic study - much less work has been done on the IT-related aspects of these agreements and their impact. The goal of this report is to scope out existing work in this area and to suggest lines of further enquiry.

Defining the scope of 'information technology based business' as the basis for our enquiry has proven to be a difficult task, as many if not most modern businesses use a wide variety of IT products. This issue is explored further in section 7.0 where we explore the role of e-commerce in these agreements: e-commerce has been defined by some as, any business transaction where one part occurs electronically, which in our computer and internet age it should be emphasised includes fax and phone. There is considerable overlap between IT on the one hand and e-commerce on the other, but other areas, such as telecommunication regulation (section 13.0), human rights concerns over privacy on WHOIS and the UDRP (section 10.0), and copyright, defamation and freedom of expression issues regarding content liability may not come under the most workable definition of the term 'e-commerce'.

In addition, the scope of our study includes 'business' and so we must be mindful of the broad impact of development and the creation of markets that is the goal of these free trade agreements, and indeed, of neo-liberal economics generally. This report's scope does not include (nor could it) the bigger scale issues of the impact of these agreements on the creation and expansion of markets and general regional development. The goal of this project is to remain neutral to the controversial issues of the validity and overall worthiness of free trade agreements, and resources from both perspectives are included in an appendix to the report.

Given the potentially large scope of both 'IT based' and 'business', we have tried to limit the discussion and analysis of the issues that have been discussed within these agreements

- though we consider topics not covered such as competition law and freedom of 
expression within our analysis. Indeed, one of the main questions uncovered by our research in the e-commerce section is to ask if some more traditional e-commerce subjects could be included in these agreements.

As to the FTAs that we analyse, we have concentrated almost completely on the Dominican Republic - Central American Free Trade Agreement (DR-CAFTA). It was chosen as it is a relatively recent multi-lateral FTA concluded with the United States. The agreement is one of several that the US has negotiated since 2000, and shares many similar features with these other agreements, thus making future comparative work easier. It also has the relatively unique situation of being signed and ratified by all but one member as of the time of this writing, the sole holdout being Costa Rica. We also have to admit a certain amount of personal interest in the region, as two of our researchers are nationals of DR-CAFTA countries.

Initially, we had hoped to engage in more comparative work with other US led FTAs and with EC involvement. However we quickly realised in our initial research that a gap existed in the literature to broadly analyse an agreement with IT-based businesses in mind. We have identified several areas that have yet to be discussed in-depth in the legal academic literature. This kind of scoping report, we hope, is the first necessary step to attempt something more comprehensive on these agreements.

This report does not feature any work on the dispute resolution frameworks contained in the various FTAs covering state-to-state and investor-state disputes. There already exists a large body of work addressing these frameworks generally. For this reason, and because the unique angle of IT-based businesses within these disputes is perhaps limited, we have not covered the dispute procedures. It is important to realise, however, that these dispute procedures can add powerful incentives to comply with the provisions of these agreements.

This work forms part of the anchor project of the Phase 1 research stream 'Legal Frameworks for Electronic Business and the Information Society' within the AHRC Research Centre. The development of a legal framework to foster e-commerce in Europe has long been regarded as the holy grail for future European prosperity ${ }^{2}$, yet following the bursting of the dot.com bubble it is even more uncertain both in the EU and the US what regulation is now appropriate. The Electronic Commerce Directive was the first major legislative measure enacted by the EU intended to address the e-commerce phenomenon as a whole, previous EC legislation having either impacted on the Internet without being specifically designed for it (e.g. the Distance Selling Directive; the Data Protection Directive), or addressing only one small sector of law (e.g. the E-Money Directives). One goal of this report is to build on the experiences and research concerning the E-Commerce Directive and seek to apply them to the area of Free Trade Agreements. This work also draws on the IP, Competition and Human Rights project of the IP and

\footnotetext{
${ }^{2}$ See earlier work in Edwards, L. \& Waelde, C., "Law and the Internet II: A Framework for Electronic Commerce”, in: Edwards, L. (ed), The New Legal Framework for E-Commerce in Europe, (2005); see also AHRC Research Centre for Studies in Intellectual Property and Technology law, Projects: Implementing European E-Commerce Legislation: <http://www.law.ed.ac.uk/ahrc/projects/view.aspx?id=8>
} 
Cultural Heritage Research Stream, developing means to combine previously disparate legal fields - including IT, trade, IP, and human rights. ${ }^{3}$

The report starts with a grounding in FTAs in general and the DR-CAFTA agreement in particular. Section 3.0 discusses some of the motivations behind signing and negotiating these agreements, and section 4.0 gives a necessarily brief overview of some of the legal framework of these agreements. Section 5.0 gives a background of the DR-CAFTA agreement in particular and in addition situates the agreement among other efforts in the region in order to give a big picture view for the reader.

Section 6.0 offers an overview of the next series of sections in which we analyse the agreement. We start with addressing e-commerce in 7.0 and intermediary liability in 8.0. We then take a step back to discuss how IP fits into FTAs generally and DR-CAFTA specifically. Following this overview, section 10.0 addresses the role of the UDRP as well as the privacy issues that arise with the use of WHOIS databases. We then briefly comment on general copyright law reforms and address the issue of anti-circumvention rules in these agreements in 11.0. We comment only briefly on competition law in 12.0, mainly to note some comparison with other US-led FTAs. We then review the telecommunication portions of the agreement in 13.0 and relate them back to our thoughts expressed in earlier sections regarding the potential contribution of IT based business. Finally we conclude by identifying areas within our work that could yield the most potential for further investigation.

\subsection{Overview of Free Trade Agreements}

\subsection{Introduction}

The early years of the $21^{\text {st }}$ century have seen a rapid increase in negotiation and implementation of FTAs between developed and developing countries - so much so that Jagdish Bhagwati used the (now famous) metaphor of a giant spaghetti bowl to describe today's trade relationships between countries. ${ }^{4}$ Even the use of the term 'regional trade agreements' as a term inclusive of FTAs is a misnomer. As noted, many recent FTAs are between geographically distant countries ${ }^{5}$ - but it is nonetheless the term used by the World Trade Organization (WTO). ${ }^{6}$ As shown in Figure 1, there has been a sharp increase in these agreements since the establishment of the WTO in 1995, with over 300 trade treaties or accessions to agreements notified to the WTO connecting virtually every

\footnotetext{
${ }^{3}$ AHRC Research Centre for Studies in Intellectual Property and Technology law, Projects: Intellectual Property, Competition and Human Rights: <http://www.law.ed.ac.uk/ahrc/projects/view.aspx?id=3>

${ }^{4}$ Bhagwati, J., "U.S. Trade Policy: The Infatuation with Free Trade Agreements", in: Krueger, J. \& Krueger, A.O., The Dangerous Drift to Preferential Trade Agreements (1995).

${ }^{5}$ Bartels, L. \& Ortino, F., “Introduction” in: Bartels, L. \& Ortino, F. (eds), Regional Trade Agreements and the WTO legal system, (2006) p.1.

${ }^{6}$ The WTO is the culmination of international efforts to create a global economy. The WTO is the result of the long Uruguay Round of the General Agreement on Tariffs and Trade (GATT), a process that lasted from 1986-1994 and culminated in the set of agreements that created the WTO. The three main agreements are the General Agreement on Tariffs and Trade (GATT), the General Agreement on Trade in Services (GATS), and the Trade-Related Aspects of Intellectual Property Rights (TRIPS).
} 
country from all corner of the globe. ${ }^{7}$ The WTO itself has projected there will be over 400 of these agreements by $2010 .{ }^{8}$ This is relevant for the work of the WTO because the multilateral system is currently the standard-bearer for the globalisation movement. The WTO provides the basic framework for the way in which international trade is conducted, and any increase in extra-WTO treaties has considerable bearing on this.

The increase in FTAs has mostly been at the bilateral level, as they offer the 'path of least resistance' to negotiating an agreement, particularly in the light of difficulties considered below which were encountered in reaching multilateral agreements. ${ }^{9}$ Indeed more than $75 \%$ of RTAs notified to the WTO by the beginning of 2005 were bilateral. ${ }^{10}$

Figure $\mathbf{1}^{11}$ The following Graph shows all RTAs notified to the GATT/WTO (19482002), including inactive RTAs, according to the year of entry into force.

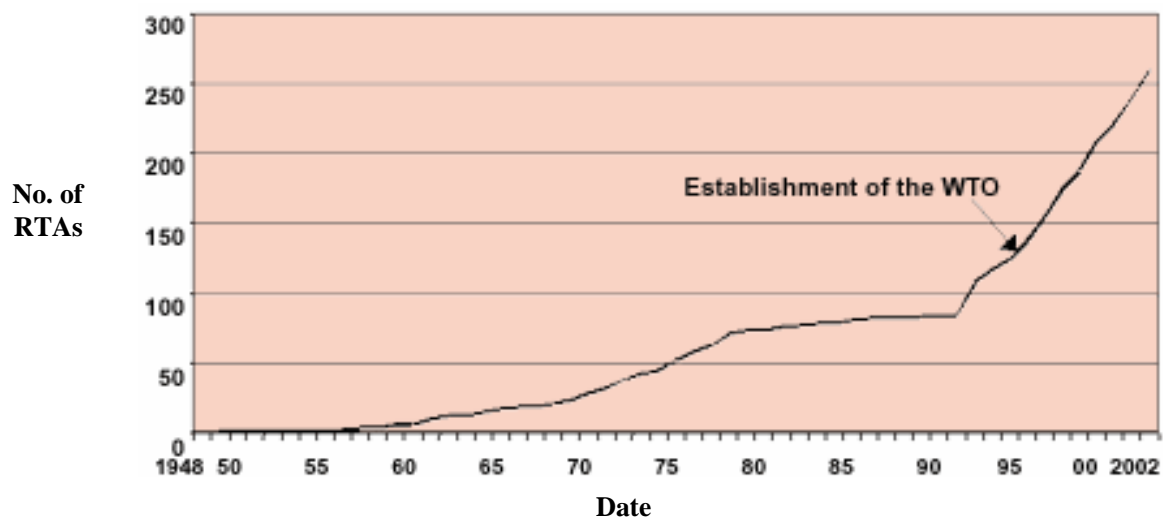

\subsection{Motivations behind FTAs}

The rise of FTAs and other regional agreements is a complex legal and political international phenomenon. Damro has collected and identified several factors in the international arena that play into the increase:

- increasing interdependence, transnationalisation and globalisation between nations; ${ }^{12}$

\footnotetext{
${ }^{7}$ For more on this point see discussion in Do, V.D. \& Watson, W. "Economic Analysis and Regional Trade Agreements” in: Bartels, L. \& Ortino, F. (eds), Regional Trade Agreements and the WTO legal system, (2006) p.7-10. WTO member are required to notify to the WTO RTAs which they join. See generally resources at WTO "Regional Trade Agreements Gateway":

<http://www.wto.org/english/tratop_e/region_e/region_e.htm>

${ }^{8}$ Lamy, P. Regional Agreements: The 'pepper' in the multilateral 'curry' (Speech 17 Jan 2007):

$<$ http://www.wto.org/english/news_e/sppl_e/sppl53_e.htm>

${ }^{9}$ Do \& Watson (2006), supra. 7.

${ }^{10}$ Crawford, J.A. \& Fiorentino, R.V. The Changing Landscape of Regional Trade Agreements, WTO Discussion Paper No. 8, p.4: <http://www.wto.org/english/res_e/reser_e/discussion_papers_e.htm>

${ }^{11}$ Graph obtained from WTO Website: <http://www.wto.org/english/tratop_e/region_e/regfac_e.htm>

${ }^{12}$ Globalisation is a complex phenomenon. In the context of the present work, it is understood as the process by which the global economy moves from a system of isolated national entities into a trade regime
} 
- the decline of US dominance in world issues and the more relaxed attitude on the part of the US towards regionalism;

- fears over the stability of the multilateral trading system; and

- changing attitudes towards neo-liberal economic development. ${ }^{13}$

In addition, there are several political aspects to consider when looking at the reasons for the increase in FTAs and why nations sign these agreements:

- the fear by countries that if they don't sign up for these agreements that they will be 'left out, or marginalised, from important international economic and political developments'. This has been called the 'marginalisation syndrome';

- to build greater regional security through economic means;

- multilateral regional agreements may have the goal of increasing negotiating leverage versus other parties; and

- resource sharing, especially in regards to smaller countries. ${ }^{14}$

On a more sinister note, FTAs can also be a means to 'lock in' domestic reforms by signing up to a difficult to change agreement ${ }^{15}$ or pursue 'back door lawmaking' by achieving through international negotiation policies what would be difficult to achieve domestically. ${ }^{16}$ As Cottier and Foltea note, '[t]he constitutional function of taming and locking-in domestic protectionist forces is a common feature both of [the] WTO and [of] preferential agreements [FTAs]. ${ }^{17}$ The process has been described by some as 'entrenching the law', 18 and is not limited to liberalising reforms in developing countries. Developed nations, such as the United States, experience the locking in of international trade policies as well. As an example of 'back door lawmaking', Yu has described the process behind the WIPO Internet Treaties (the WCT and WPPT) as a means by which domestic companies and trade interests in the United States pursued reforms that they could not achieve via normal channels in the US Congress. After these agreements were ratified, the US Congress was then given treaty compliance as a reason to enact the reforms it had previously rejected. ${ }^{19}$

where different barriers disappear to give way to a global marketplace. See: Hill, C.W. International Business: Competing in the Global Marketplace (1997) 5.

${ }^{13}$ Damro, C., “The Political Economy of Regional Trade Agreements” in Bartels, L. \& Ortino, F. (eds), Regional Trade Agreements and the WTO legal system (2006), p. 27. See also discussion in Crawford \& Fiorentino, supra. 10.

${ }_{14}$ Damro (2006), supra. 13, pp.30-36.

${ }^{15}$ Ibid. p.36.

${ }^{16}$ Yu, P.K., “Anticircumvention and Anti-Anticircumvention” (2006) 84 Denv. U. L. Rev. 13, p.54; see also Yu, P.K., “Currents and Crosscurrents in the International Intellectual Property Regime” (2004), 38 Loy.

L.A. L. Rev. 323, pp. 397-98.

${ }^{17}$ Cottier, T. \& Foltea, M., “Constitutional Functions of the WTO and Regional Trade Agreements”, in: Bartels, L. \& Ortino, F. (eds), Regional Trade Agreements and the WTO legal system, (2006) 45.

${ }^{18}$ Yu, P.K., (2006) supra. 16, p.58.

${ }^{19}$ Yu, P.K., (2004) supra. 16, p.397-98. 


\subsection{Conclusion}

A wide variety of factors clearly influence a state's decision to negotiate an FTA. Justifications may be as diverse as simply 'being polite ${ }^{20}$ to obtaining more aid from the European Union. ${ }^{21}$ In addition, FTAs are often easier to negotiate than multilateral trade agreements within the WTO system. This is illustrated by the relative success of the plurilateral Ministerial Declaration on Trade in Information Technology Products ${ }^{22}$, which was concluded by 29 nations at the Singapore WTO Ministerial Conference ${ }^{23}$. The Declaration was the precursor to the WTO Information Technology Agreement (ITA) and calls for all participants to eliminate duties on IT products specified within the agreement ${ }^{24}$. The Declaration and subsequent Agreement thereby achieved trade liberalisation within the IT-sector beyond that discussed during the Uruguay round ${ }^{25}$. However, since its implementation, the number of participants to the ITA has grown to 70 , representing about $97 \%$ of the world trade in IT products ${ }^{26}$, and negotiations on the expansion of product coverage and non-tariff barriers to trade have proceeded with little success $^{27}$. Regional and bilateral FTAs may, however, provide a means of updating multilateral or even plurilateral trading rules to reflect the impact of emerging technologies.

\subsection{Legal Framework of FTAs}

All members of the DR-CAFTA agreement have been members of the WTO from its beginnings in 1995. As such, they are all subject to the rules that the WTO has regarding giving trade preferences to other members. A full analysis of the place of FTAs within the WTO system is outside the scope of this report. ${ }^{28}$ However, in this section, we briefly set up the overall principles of the WTO, and how FTAs fit as an exception to these principles. Finally in section 4.3, we cover the relatively special case of IP and its role within FTAs, in comparison with exceptions to free trade in goods and services.

\footnotetext{
${ }^{20}$ Do \& Watson (2006), supra 7, p.9.

${ }^{21}$ Damro (2006), supra. 13, p.34.

${ }^{22}$ WTO, Ministerial Declaration on Trade in Information Technology products, WT/MIN(96)/16: $<$ http://www.wto.org/english/docs_e/legal_e/itadec_e.pdf >

${ }^{23}$ WTO, Trade Topics: Information Technology Agreement:

$<$ http://www.wto.org/english/tratop_e/inftec_e/inftec_e.htm>

${ }^{24}$ Ibid. Note: Developing nations have been given an extended period for implementation.

${ }^{25}$ WTO News, Statement by Pascal Lamy at the WTO Information Technology Symposium (March 28, 2007): <http://www.wto.org/english/news_e/sppl_e/sppl58_e.htm>

${ }^{26}$ WTO, Information Technology Agreement - Introduction:

<http://www.wto.org/english/tratop_e/inftec_e/itaintro_e.htm>

${ }^{27}$ See also the Annual Reports of the Committee of Participants on the Expansion of Trade in Information Technology Products: available from <http://www.wto.org/english/tratop_e/inftec_e/inftec_e.htm>; for further information on the ITA, see annex 1 of the Research Appendix to this report.

${ }^{28}$ However, the authors have included resources in the appendix for those interested in further research into the subjects raised.
} 


\subsection{Structure of the WTO}

The WTO consists of 150 members from all over the world. Its membership is open not only to states, but also to RTAs, with the European Community the only such member.

In general, WTO rules are based on two main principles:

1. Most-favoured-nation (MFN): Generally, members must treat all of their trading partners the same, and thus grant them all the same treatment as if they were the 'most favoured' trading partner.

2. National treatment: Foreign goods, services, and IP rights should be treated the same within each member.

These two standards are known as the non-discrimination principles.

\subsection{How FTAs fit in the WTO agreements}

An FTA is by definition a set of preferential rules that are granted to some, but not all, other WTO members. As such, they may violate the normal standards of nondiscrimination outlined above. These exceptions are governed by specific rules laid out in Article 24 GATT (goods), Article 5 and 5bis GATS (services), and in the Technical Barriers to Trade (TBT) Agreement and the Sanitary and Phyto-Sanitary (SPS) Agreement. The Rules of Origin agreement still applies.

There are three basic criteria for an FTA:

1. substantial trade coverage;

2. abolition of internal trade restrictions; and

3. the avoidance of severe barriers to third party members of the WTO. ${ }^{29}$

Note that these rules don't apply for agreements with non-WTO members - members are free to negotiate with these countries in whatever manner they wish.

\section{3 'Ratcheting up'}

The trade rules on IP and FTAs differ slightly to those involving customs duties and other trade restrictions. It should be noted that the TRIPS agreement, an Annex to the WTO Agreement which addresses IP, sets minimum standards of protection to be provided by WTO members. These minimum standards can be increased, however, by other agreements and thus it can be thought of as setting a floor and not a ceiling. The mostfavoured nation principle in TRIPS requires that the standards set by FTAs be given to all countries, not just other parties to the agreement:

"With regard to the protection of intellectual property, any advantage, favour, privilege or immunity granted by a Member to the nationals of any other

${ }^{29}$ Cottier \& Foltea (2006), supra. 17, pp.47-51. 
country shall be accorded immediately and unconditionally to the nationals of all other Members.”30

The process where IP rights granted under a free trade agreement get expanded to all trading partners has been referred to as 'ratcheting up', because of its one-way effect of increasing IP protection. ${ }^{31}$

\subsection{Background of DR-CAFTA}

\subsection{Overview of the agreement}

DR-CAFTA is a multilateral FTA negotiated between the United States and six Latin American countries. Originally, the agreement was negotiated between the US and the Central American countries of Costa Rica, El Salvador, Guatemala, Honduras, and Nicaragua and was known simply as CAFTA. In 2004 the Dominican Republic joined the agreement and the name was changed to 'DR-CAFTA' (or sometimes CAFTA-DR).

The agreement, like many other FTAs, covers a relatively wide variety of trade aspects, including chapters on government procurement, financial services, and even labour and environmental chapters. The present report is primarily concerned with three chapters of the agreement: Chapter 13 Telecommunications, Chapter 14 Electronic Commerce and Chapter 15 Intellectual Property Rights. In addition, it should be noted that the DRCAFTA also contains dispute resolution provisions for investors ${ }^{32}$ and for member states. $^{33}$

In order to provide some background information about the DR-CAFTA, the following are included: details of each country involved; a timeline of the DR-CAFTA; and a timeline of bilateral and multilateral agreements that the United States has concluded since 2001. These agreements, as will be discussed throughout the report, share many similarities and so are important to keep in mind when discussing some of the comparative aspects.

Table 1: DR-CAFTA countries ${ }^{34}$

\begin{tabular}{|l|l|l|l|}
\hline Flag & Name & Population (2005 estimate) & $\begin{array}{l}\text { GDP (2005 estimate in } \\
\text { current USD) }\end{array}$ \\
\hline
\end{tabular}

${ }^{30}$ Article 4, WTO Agreement on Trade-Related Aspects of Intellectual Property Rights (TRIPS)(April 15, 1994): <http://www.wto.org/english/docs_e/legal_e/27-trips_05_e.htm>

${ }^{31}$ Drahos, P., "Bits and Bips. Bilateralism in Intellectual Property" (2001), 4(6) J. World Intel. Prop. 791.

${ }^{32}$ DR-CAFTA, supra. 1, Chapter 10

${ }^{33}$ DR-CAFTA, supra. 1, Chapter 20

${ }^{34}$ Statistics obtained from the World Bank website: <http://www.worldbank.org/data> 


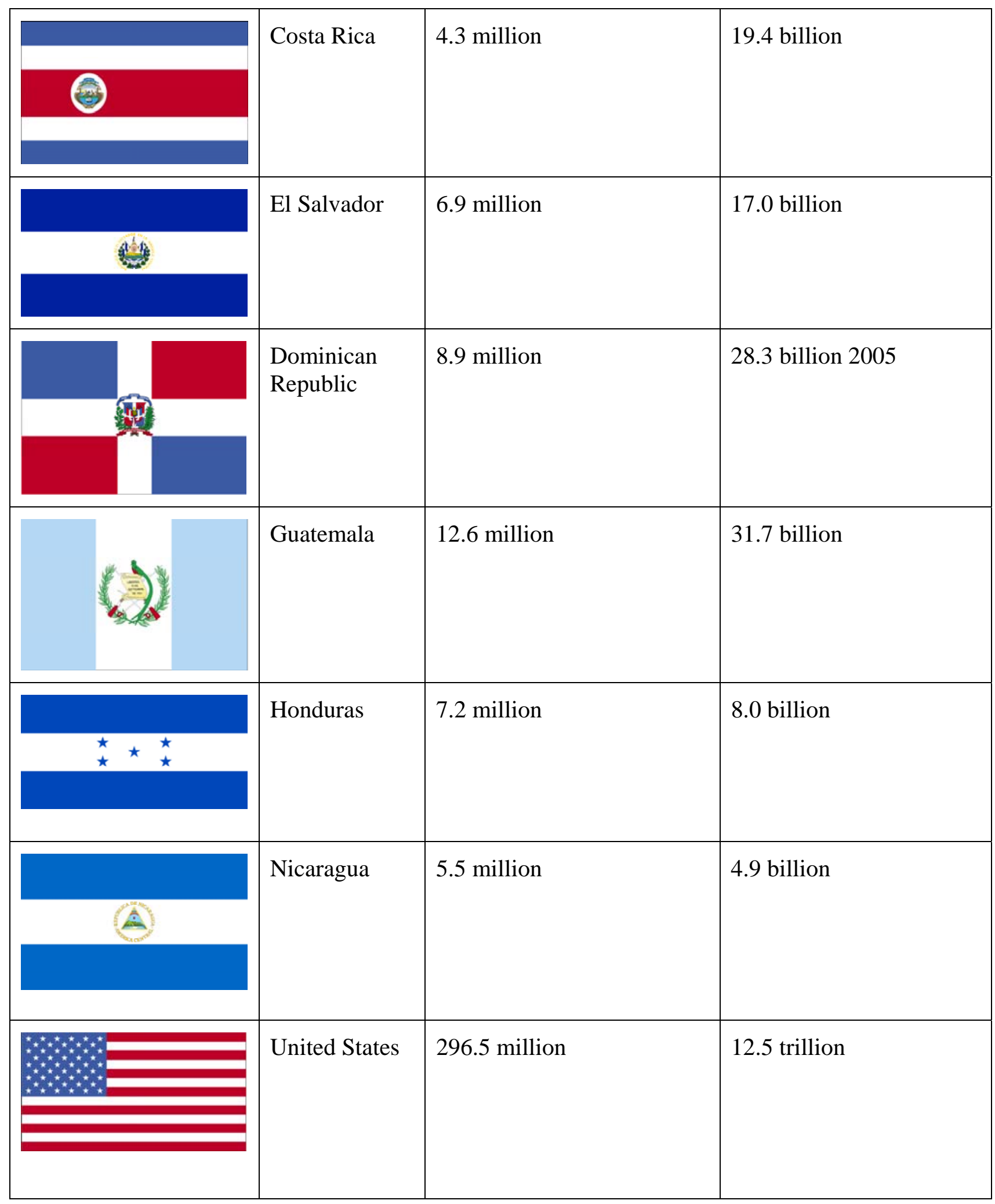


Timeline 1: DR-CAFTA Agreement

\begin{tabular}{|c|c|}
\hline Date & Action on DR-CAFTA \\
\hline 6 August 2002 & $\begin{array}{l}\text { President Bush signs the Bipartisan Trade Promotion Authority } \\
\text { Act of } 2002 \text { into law }\end{array}$ \\
\hline 8 January 2003 & $\begin{array}{l}\text { Negotiations begin between the United States and El Salvador, } \\
\text { Guatemala, Honduras, Nicaragua and Costa Rica. }\end{array}$ \\
\hline 17 December 2003 & $\begin{array}{l}\text { Agreement reached between US and El Salvador, Guatemala, } \\
\text { Honduras and Nicaragua }\end{array}$ \\
\hline 25 January 2004 & Costa Rica agrees to the text. \\
\hline 28 May 2004 & $\begin{array}{l}\text { CAFTA signed by United States, El Salvador, Guatemala, } \\
\text { Honduras, Nicaragua and Costa Rica. }\end{array}$ \\
\hline 5 August 2004 & $\begin{array}{l}\text { Dominican Republic signs the agreement. Agreement is renamed } \\
\text { DR-CAFTA. }\end{array}$ \\
\hline 17 December 2004 & El Salvador ratifies. \\
\hline 3 March 2005 & Honduras ratifies. \\
\hline 10 March 2005 & Guatemala ratifies. \\
\hline 2 August 2005 & United States ratifies. \\
\hline 10 October 2005 & Nicaragua ratifies \\
\hline 1 March 2006 & Entry into force in El Salvador. \\
\hline 1 April 2006 & Entry into force in Honduras and Nicaragua \\
\hline 1 July 2006 & Entry into force in Guatemala. \\
\hline 1 March 2007 & Entry into force in Dominican Republic \\
\hline
\end{tabular}

Timeline 2: Date of signing of FTAs by the United States since 2000. (Note: signing does not mean full approval or ratification by the respective domestic governments)

\begin{tabular}{|l|l|}
\hline $\begin{array}{l}\text { Date of signature } \\
\text { (not ratification) }\end{array}$ & Agreement name \\
\hline OCTOBER 2000 & Jordan Free Trade Agreement \\
\hline MAY 2003 & Singapore Free Trade Agreement \\
\hline JUNE 2003 & Chile Free Trade Agreement \\
\hline MAY 2004, & Australia Free Trade Agreement \\
\hline MAY 2004 & CAFTA \\
\hline AUGUST 2004 & DR CAFTA (with Dominican Republic) \\
\hline JUNE 2004 & Morocco Free Trade Agreement \\
\hline
\end{tabular}




\begin{tabular}{|l|l|}
\hline SEPTEMBER 2004 & Bahrain Free Trade Agreement \\
\hline JANUARY 2006 & Oman Free Trade Agreement \\
\hline APRIL 2006 & Peru Trade Promotion Agreement \\
\hline NOVEMBER 2006 & Colombia Trade Promotion Agreement \\
\hline DECEMBER 2006 & Panama Free Trade Agreement \\
\hline MARCH 2007 & Republic of Korea Free Trade Agreement \\
\hline NEGOTIATING & Malaysia Free Trade Agreement \\
\hline NEGOTIATING & Southern African Customs Union Free Trade Agreement \\
\hline NEGOTIATING & Thailand Free Trade Agreement \\
\hline NEGOTIATING & United Arab Emirates Free Trade Agreement \\
\hline
\end{tabular}

\subsection{Arguments for and against DR-CAFTA}

As noted the agreement has been signed by all of the participating countries, ratified by all but Costa Rica, and come into force in several of the countries. But a review of the reasons proposed for and against DR-CAFTA can help understanding of the agreement:

The following 'for' arguments were some of those proposed by the Office of the United States Trade Representative (USTR):

1. Market size: The USTR argues that 'CAFTA-DR is a larger U.S. export market than Russia, India and Indonesia combined. The American Farm Bureau Federation estimates CAFTA could expand U.S. farm exports by $\$ 1.5$ billion a year. ${ }^{35}$

2. Investor protection: The agreement provides dispute resolution provisions for investors against member states under certain circumstances. ${ }^{36}$

3. Equal access to markets: Many of the products already entering the US from these countries were already entering duty-free, but there was not necessarily reciprocal access. 'Today, nearly $80 \%$ of products from Central America and the Dominican Republic already enter the U.S. duty-free, partly because of unilateral preference programs such as the Caribbean Basin Initiative (CBI) and the Generalized System of Preferences (GSP). America's market is already open. CAFTA opens the region's markets to goods, services, and farm products from the United States. ${ }^{37}$

\footnotetext{
${ }^{35}$ Office of the United States Trade Representative (USTR), The Case for CAFTA:

$<$ http://www.ustr.gov/Trade_Agreements/Bilateral/CAFTA/Briefing_Book/Section_Index.html>

${ }^{36}$ USTR, Short Summary of the CAFTA:

<http://www.ustr.gov/Trade_Agreements/Bilateral/CAFTA/Briefing_Book/Section_Index.html>

${ }^{37}$ USTR, The Case for CAFTA, supra. 29; See also USTR, CAFTA will shrink the US Trade Deficit:

$<$ http://www.ustr.gov/Trade_Agreements/Bilateral/CAFTA/Briefing_Book/Section_Index.html> (outlining the tariffs on certain goods.)
} 
4. Advantages in competing with Asia: By cooperating, the DR-CAFTA countries can compete with Asia in the textiles market because of the expiration of textile quotas. $^{38}$

5. Promoting 'freedom and democracy': By approving the DR-CAFTA agreement, the USTR argued that '[DR-]CAFTA is a way for America to support freedom, democracy and economic reform in our own neighbourhood. ${ }^{39}$

The main argument for the defenders of the agreement from the Central American and Dominican economies is that it will attract foreign investment and it will also increase exports by opening up the American market. For example, in Nicaragua during the first 30 days of the implementation of the agreement, the country received an additional $\$ 8$ million USD in sales to the U.S.A. Nicaraguan sales to the U.S. during April 2006 \$27.8 million USD, while the same figure for April 2005 was \$24.1 million USD. For the total of 2006, it is calculated that there has been an increase in exports to the U.S. of up to 33\% more than the same period before the agreement. ${ }^{40}$

The following are arguments generally put forward by those opposing the agreement: ${ }^{41}$

1. Access to medicines: Professional medical bodies and local pharmaceutical industries, particularly in Central America, have expressed concern that the implementation of DR-CAFTA will have severe impact on the capacity of public health systems to purchase and/or produce generic medicines, as they argue that compulsory licensing of patented medicines will be eroded by the agreement. $^{42}$

2. Increased foreign competition: Serious concerns have been raised by labour unions and local industries about opening the local markets to increased competition from the United States. There is widespread fear that many small

\footnotetext{
${ }^{38}$ Ibid.

${ }^{39}$ Ibid.; See also Hess Araya, C. "Libertad de comercio y acceso a la Internet en Costa Rica", 17 Alfa Redi (1999): <http://www.alfa-redi.org/rdi-articulo.shtml?x=382>

${ }^{40}$ Examples of this type of rhetoric are numerous. For some examples, see Gonzalez-Acosta, E.D., "CENTRAL AMERICA - CAFTA and the U.S. Patron-Client Relationship with Dominican Republic and Central America” (May 24, 2007), Alterinfos América Latina:

<http://www.alterinfos.org/spip.php?article1385 >; and Frente Nacional Por La Defensa de Los Derechos Económicos y Sociales, Los TLC arma de agresión imperialista contra los pueblos (2006):

<http://www.nodo50.org/caminoalternativo/boletin/107-8.htm >

${ }^{41}$ There is a wide range of disparate opposition to the agreements, both in the United States and in the central countries involved. These range from labour movement (particularly from public workers unions), to special corporate and private interests threatened by enhanced international competition. See:

Barrionuevo, A \& Becker, E. “Fewer Friends in High Places for This Lobby” (June 2, 2005), New York Times: <http://www.nytimes.com/2005/06/02/business/02sugar.html?pagewanted=print>

${ }^{42}$ Avalós, A., "País defiende acceso a medicinas genéricas” (October 10, 2003), La Nación, p.6; Comisión de Asuntos Jurídicos, Ventajas y desventajas del CAFTA en el sector salud (2005), Briefing paper, Asamblea Legislativa de Costa Rica:

$<$ http://www.asamblea.go.cr/servicios_tecnicos/w_dst/contenido/documentos/documentos\%20dst\%20ofici os\%5Cct\%5CCTI2005\%5CCON-I-025-2005.pdf>
} 
and medium firms will go out of business because it will be impossible for them to compete against large multinational corporations. ${ }^{43}$

3. Import culture: This is related to the previous point. With increased access from foreign goods, imports of "luxury" goods will increase, and therefore the local market will move to a low-earning, low-cost, low-wage specialisation. ${ }^{44}$

4. Privatisation: DR-CAFTA will result in the privatisation of many publiclyowned services, particularly in the telecommunications area. This will seriously increase prices for providers, and will make these services more expensive for consumers. ${ }^{45}$

5. Loss of sovereignty: In a corner of the world that has experienced American political intervention, DR-CAFTA is seen by some as another attempt by American interests to dominate the area. ${ }^{46}$

\subsection{Agreements and institutions}

FTAs certainly do not happen in a vacuum. There are several other institutions, both global and regional, that form part of the same context. As pointed out in the above table, the US is currently attempting to conclude several other treaties, all of which share some similar features to the DR-CAFTA agreement. But before all the recent flurry of activity surrounding FTAs on the part of the US, there was an earlier plan for greater integration of the Americas - The Free Trade Area of the Americas (FTAA).

\subsubsection{Free Trade Area of the Americas (FTAA)}

The Free Trade Area of the Americas is a plan to reduce trade barriers and promote integration within the Americas. The idea was first put forth by President George Bush in 1990 under the name 'Enterprise for the Americas Initiative'. Since this time, the FTAA has gone through a series of negotiation rounds, officially beginning at the Summit of the Americas in Miami in 1994. The last round took place in Mar del Plata in Argentina in 2005. The Mar del Plata round has been the last consideration of the FTAA and most consider that the plans for the agreement have stalled. ${ }^{47}$ The number of FTAs already concluded and in the process of negotiation by the United States in the region could be seen as an attempt to achieve the goals of the FTAA through other means.

\subsubsection{World and regional institutions}

Some other institutions (not to mention a myriad of other factors) have a part in analysis of the law and politics of a region. The following is a selected list of institutions of

\footnotetext{
${ }^{43}$ For a typical opinion expressing this point of view, see: Solís, O., “¿No ha estudiado el TLC?” (April 5 2007), La Nación: <http://www.pac.or.cr/sitio1/paginas/noticias.php?id=785\&seccid=1\&registrar=1>

44 Ibid.

${ }^{45}$ For example, all telecommunication services in Costa Rica are publicly owned.

${ }^{46}$ USTR, supra. 30.

${ }^{47}$ For some background about the FTAA's difficult negotiation see Vivas-Egui, D., Regional and bilateral agreements and a TRIPS-plus world: the Free Trade Area of the Americas (FTAA) (2003), TRIPS Issues Papers 1, Quaker United Nations Office, pp.12-13.
} 
relevance to Latin America and the Caribbean, and is not an attempt at a comprehensive outline. The first group consists of broader international institutions, while the second grouping concentrates on regional integration efforts. ${ }^{48}$ As some will be better known to some readers than others, a brief description is provided in each case.

- International Monetary Fund (IMF): An international organisation created in 1945 from the Bretton Woods meeting in order to foster global monetary cooperation and facilitate international trade. The IMF has considerable power towards developing countries as its policies tend to shape economic trends at national level.

- World Bank: Also created in 1945 from the Bretton Woods meeting, the World Bank is a group of international organisations created to assist with post-World War reconstruction in Europe. Nowadays its role is to provide financial advice to countries towards development.

- Inter-American Development Bank: The IADB was established in 1959 in order to provide financial assistance to the countries in the American continent. This assistance mostly takes the shape of governmental loans. All member states of the IADB have a stake in the bank, but the U.S. holds 30\% of the stock.

- United States Agency for International Development: USAID is an American government agency in charge of non-military foreign aid.

- World Intellectual Property Organisation: WIPO was created in 1967 as part of the United Nations institutional system. The function of WIPO is to administer the existing and future international treaties regarding intellectual property protection, and to promote harmonization of national legislation. WIPO administers twenty-three different treaties relating to intellectual property subjects, including the 1996 WIPO Copyright Treaty.

- United Nations Educational, Scientific and Cultural Organization: UNESCO, as its name clearly denotes, is the United Nations body which has direct responsibility for handling international education, scientific and cultural issues.

- The World Trade Organization: As noted above, the WTO is the culmination of international efforts to create a global economy. The WTO is the result of the long Uruguay Round of the General Agreement on Tariffs and Trade (GATT), a process that had its origins in the end of the Second World War, and included lengthy discussions that would eventually end up in an international framework for world trade. The Uruguay Round of talks lasted from 1986-94 and culminated in the set of agreements that created the WTO. The three main agreements are the General Agreement on Tariffs and Trade (GATT), the General Agreement on Trade in Services (GATS), and the Trade-Related Aspects of Intellectual Property Rights (TRIPS).

The following is a selected list of other regional integration within Latin America and the Caribbean:

\footnotetext{
${ }^{48}$ All of the following institutional descriptions are part of the handouts for the course International IP and IT Institutions, Law and Policy, at the University of Edinburgh written by Guadamuz. A.
} 
- North American Free Trade Agreement: NAFTA is a regional trade agreement negotiated by the US, Mexico and Canada, which came into effect in 1994.

- Latin American Free Trade Association: LAFTA is a loose coalition of Latin American countries that came together in the 1960's with the intention of creating a Latin American Free Trade Agreement, similar to the European Union.

- Central American Common Market: The CACM is an early attempt at a free trade area from five Central American countries, Guatemala, El Salvador, Honduras, Nicaragua and Costa Rica. While it has existed since 1960, its relevance has not been greatly felt. There is a Central American parliament which exists to harmonise legislation, but the absence of Costa Rica from the political tool has seriously crippled the institution.

- Andean Community of Nations: CAM was an agreement of Bolivia, Colombia, Ecuador, Peru and Venezuela, formed in the Cartagena Agreement of 1969. While the Andean Community had significant organisation and relevance, it has been badly hit by the departure of Venezuela (see ALBA).

- Mercosur: is another regional agreement, created in 1991 by the Treaty of Asunción between Argentina, Argentina, Paraguay, Uruguay and Venezuela.

- CARICOM: The Caribbean Community: CARICOM is a regional agreement between 15 countries of the Caribbean region. It was created in 1972 by English-speaking countries members of the Caribbean Free Trade Association (CARIFTA), but it now includes Dutch and French-speaking former colonies.

- ALBA: see below.

There are other regional plans in Latin America which influence the outcome of agreement such as those considered. These are the Plan Puebla Panamá ${ }^{49}$ and the Initiative of South American Regional Infrastructure. ${ }^{50}$ The experiences of the United States, Canada, and Mexico in the NAFTA in particular could prove a fruitful ground for comparative research in the future.

\subsection{DR-CAFTA political aspects}

A complete survey of the politics surrounding the adoption and context of DR-CAFTA fall outside the scope of this report, however it is beneficial to understand some of the issues that come into play when discussing regional issues in Latin America in general and the free trade agenda of the United States in particular.

\footnotetext{
${ }^{49}$ Plan Puebla Panamá: <http://www.planpuebla-panama.org/main-pages/concepto.htm>

${ }^{50}$ Initiative for Integration of South American Regional Infrastructure (CAF):

<http://www.caf.com/view/index.asp?ms=11\&pageMs=14448>
} 


\subsubsection{Trade Promotion Authority}

The high rate of recent United States activity regarding FTAs could be traced, in part, to the authority of the Executive branch of the United States government to 'fast track' these agreements. This authority was granted to the Executive in the Bipartisan Trade Promotion Authority Act of 2002, and is the latest in a series of agreements between Congress and the Executive that balance out the authority between the two branches to conduct these sorts of agreements. Though externally these agreements are considered treaties, within the domestic legal structure of the United States these agreements do not have treaty status, which means that they go through the normal legislative process (albeit with certain constrains, see below) whereas treaties are subject to approval by $2 / 3$ of the US Senate. ${ }^{51}$

The 'fast track authority' or 'Trade Promotion Authority (TPA)' as it is variously known, sets a distinct timetable for voting and discussion and prevents any amendments to the bill the President submits to Congress implementing the negotiated free trade agreement. The bill, in order to be enacted must pass simple majorities in both houses of Congress.

This authority expires on 30 June 2007 unless it is renewed by the US Congress. The renewal of this power, as well as the ability for these bills to attain Congressional approval, plays into the politics between the Democratic and Republican parties. The change in control in the House and Senate from Republican to Democrat in the 2006 election was seen in part by some as a result of the position by the candidates on free trade issues. ${ }^{52}$ Regardless of political persuasion or the immediate extension of the TPA because of the critical nature of international trade it is really a matter of how trade issues will be addressed in the future rather than if they will be addressed at all.

The authority granted to the Executive under the Bipartisan Trade Promotion Authority Act of 2002, includes specific objectives related to e-commerce and IP, which are discussed further in their respective sections of this report.

\subsubsection{The Shadow of 301}

Section 301 of the Trade Act of 1974 authorises the use of trade sanctions and other tools against countries that have been identified as, in the opinion of the US, violating or denying rights under US trade agreements or as having negatively affect US commerce. Every year, the United States Trade Representative releases a series of watch lists in a report on the status of IP and related laws in countries throughout the world. The watch list is a tool to try to increase pressure on these countries to alter their laws (even if those laws in fact comply with TRIPS), prior to the United States attempting to enact further sanctions. Countries which have the worst trade policies will be designated "Priority Foreign Countries," and at the end of an ensuing investigation, risk having trade sanctions

${ }^{51}$ Wright, L., "Note: Trade Promotion Authority: Fast Track for the Twenty-First Century?” (2004) 12 Wm. \& Mary Bill Rts. J. 979.

${ }^{52}$ Slevin, C., \& Tucker, T., “The Fair Trade Sweep” (2006), The Democratic Strategist:

$<$ http://www.thedemocraticstrategist.org/0701/slevintucker.php> 
enacted against them. Countries can also be placed on other lists which do not result in immediate trade sanctions, but that may result in future action being taken. These other lists are the 'Priority Watch List' and 'Watch List'. ${ }^{53}$

Several DR-CAFTA member countries have, in the past, been on the list. Most recently, Costa Rica, for example, has been recommended for inclusion on this year's list by the International Intellectual Property Alliance (IIPA). ${ }^{54}$ In the IIPA's recommendations for the 2007 Special 301 report, they comment that:

"The copyright industries report that no significant improvement to halt widespread copyright piracy in Costa Rica occurred in 2006. Optical disc piracy is on the rise and street piracy remains pervasive. Most disturbingly, there has been little-to-no prosecutorial interest in pursing criminal copyright cases, and this problem rests at the higher levels of the Costa Rican Government." 55

\subsubsection{ALBA}

The controversial Bolivarian Alternative for the Americas (Alternativa Bolivariana para las Américas or ALBA) is also noteworthy. The agreement has been triumphed by Venezuelan President Hugo Chávez Frías as an alternative to traditional neo-liberal free trade models and, therefore, as a necessary alternative to the US-led FTAA ${ }^{56}$. ALBA's emphasis on social policy and the sharing of resources, rather than on trade, arguably makes it 'the first attempt at regional integration that is not based primarily on trade liberalisation but on a new vision of social welfare and equity ${ }^{57}$.

As an example of the 'new vision' of ALBA, the first agreement between Cuba and Venezuela involved an exchange of doctors and medical training from Cuba for subsidized oil imports from Venezuela. ${ }^{58}$ Later initiatives include TeleSUR, a Latin American television network aimed at greater regional integration and owned by several different nations in the region, ${ }^{59}$ and Operation Miracle, a project between Venezuela and Cuba to offer free eye surgery for citizens in the region. ${ }^{60}$

\footnotetext{
53 Pechman, R.J., "Seeking Multilateral Protection for Intellectual Property: The United States "TRIPs" over Special 301” (1998), 7(1) Minnesota Journal of Global Trade 179.

${ }^{54}$ International Intellectual Property Alliance, 2007 Special 301 Report (2007) p.25:

$<$ http://www.iipa.com/rbc/2007/2007SPEC301COSTARICA.pdf>

${ }^{55}$ Ibid.

${ }^{56}$ Radio Habana Cuba, ALBA Key Speeches: <http://www.radiohc.cu/ingles/alba/discursos/chavez1.htm>

${ }^{57}$ Harris, D., \& Azzi, D., ALBA Venezuela's answer to "free trade": the Bolivarian Alternative for the Americas (2006), Focus on the Global South: <http://www.focusweb.org/alba-venezuela-s-answer-to-freetrade-the-bolivarian-alternative-for-the-ame.html $>$

${ }^{58}$ Agreement between the President of the Bolivarian Republic of Venezuela and the President of the Council of State of Cuba, for the Application of the Bolivarian Alternative for the Americas (December 14, 2004): <http://www.mltoday.com/Pages/NLiberation/Cuba-VenezPact.html >

${ }^{59}$ See TeleSUR's mission statement: <http://www.telesurtv.net/secciones/concepto/index.php>

${ }^{60}$ See Fawthrop, T., “Havana’s Operation Miracle helps eye patients see the light” (Nov. 26, 2005) Scotsman: <http://news.scotsman.com/health.cfm?id=2305142005>
} 


\subsubsection{Other issues}

In the end, partner countries to the United States for these agreements are also inevitably caught up in political issues. Cuba, as ever, is not included in US-backed or influenced plans for the region, and with the rise of Hugo Chavez, Venezuela is often excluded as well. Past US agreements in the region have included, for example, provisions prohibiting the support of communist political movements. ${ }^{61}$

On a more global scale, free trade and globalisation both remain a controversial political issue, with protest often occurring at the site of major international trade negotiations. Edinburgh, the home to the AHRC Research Centre, has been the site of such protests, such as those occurring during the G8 summit at Gleneagles in 2005.

\subsection{Impact for IT-based business}

In the following sections we discuss the different areas that IT-based business and FTAs intersect. In 7.0, we discuss the overlap with areas traditionally associated with ' $\mathrm{e}$ commerce' and address how IT lawyers and trade lawyers might look at these issues differently. We expand on these issues of e-commerce by specifically addressing the impact of this agreement on the people who make the 'e' happen: ISPs. Section 8.0 addresses intermediary liability - the legal standards to which ISPs can be held and when liability can be imposed in respect of traffic and conduct over and on their equipment. In the next block of the report we address IP issues as they relate to IT-based businesses. We start, in section 9.0 addressing the area of IP in general. Then we tackle the place of domain names within the FTA framework in section 10.0, including addressing privacy in the context of WHOIS requirements. Then we address issues of copyright law in 11.0 and flag up some issues that could prove problematic. Next we address Telecommunications aspects in section 12.0. We then offer some conclusions in section 13.0, and outline a possible workshop in the final section, 14.0.

\subsection{E-Commerce}

E-commerce is a term with few generally accepted definitions. At its broadest, it can include any commercial transaction in which one part, such as advertising or the delivery of the product or service, happens electronically. This definition spans from simply using a telephone or fax machine to place an order for a product to more complex transactions making use of the internet.

Even at its widest level, e-commerce encompasses a smaller area within the broad scope of 'IT-based businesses', as 'IT can encompass '[t]he entire array of mechanical and

${ }^{61}$ Caribbean Basin Economic Recovery Act, 19 USC 2702 (b)(1) 
electronic devices which aid in the storage, retrieval, communication, and management of information - from typewriters to computers to copying machines. ${ }^{62}$

In this scoping report, we make no effort to try to settle on one definition. Instead we concentrate on the areas that typify research into e-commerce, both from an IT lawyer's perspective and from a trade law perspective. We then go over some of the social and legal issues that come into play when considering the expansion of e-commerce in the region. We briefly quote some of the US goals for e-commerce in its FTAs, and finally, we draw some conclusions for further study and exploration.

\subsection{E-commerce from an IT-lawyer's perspective}

Within the IT-law field, we tend to look at the following when discussing e-commerce:

- intellectual Property and its impact on the field, including domain name issues and peer-to-peer file sharing;

- internet governance;

- taxation and e-payments;

- contracting electronically;

- $\quad$ security and reliability issues, including spam and DDOS attacks;

- authentication issues and digital signatures;

- consumer protection issues;

- content regulation issues, including defamation and pornography;

- competition law aspects of e-commerce related businesses;

- human rights issues, in particular privacy;

- jurisdictional issues and the internet; and

- telecoms issues, such as net neutrality and the interplay between telecoms policy and the law.

This list was created by sampling the contents of several leading books on 'e-commerce' and 'cyberlaw' as a means of beginning to address the potential issues of IT law and FTAs. This list is not exhaustive, and there certainly are other areas that could be included in it. We address one of these other areas, intermediary liability, in a specific section later in this report. Within the context of FTAs, the first (IP) and last (telecoms) do tend to be addressed directly in the agreements (in separate sections). Because they are quite distinct areas, and because they are treated that way in these agreements, we have also addressed these topics separately.

As a side note regarding the scope of this report, taxation issues involving e-commerce can be quite complex. In addition, FTAs do not tend to address tax issues in too much detail, as these issues are usually confronted in specific tax treaties. As such, they fall outside the scope of this project.

\footnotetext{
${ }^{62}$ School of Information Resources \& Library Science, University of Arizona, The Information Professional’s Glossary: <http://www.sir.arizona.edu/resources/glossary.html>
} 
The remaining areas present fruitful questions for potential further study. Some work has been done by other academics and researchers in the field, though without necessarily referencing the ability to address these issues within the FTA framework. Some example sources looking at these issues within the Latin American context are included in the appendix.

One question that arises from our research: Could further coordination of internet governance take place via the WTO or FTAs rather than through other international institutions or initiatives such as the Internet Governance Forum? ${ }^{63}$ Much has been commented upon the shift of IP law to the WTO from WIPO in the 1990's, and one line of enquiry could be into the possibility of a similar shift in the above areas. ${ }^{64}$ All of the areas referenced have some aspect related to trade, and thus could conceivably be addressed in either the WTO or in an FTA. Indeed a key question for further study could even be framed: 'Why hasn't more work in these areas been done in FTAs or in the WTO?'

\subsection{Trade law perspectives}

Trade lawyers, in contrast to those who focus on IP or IT law, tend to look at different issues when considering e-commerce within the context of the WTO and FTAs.

The WTO started looking officially at issues raised by e-commerce during its Ministerial Meeting in Geneva in May 1998. At this meeting, member states ratified the Ministerial Declaration on Electronic Commerce ${ }^{65}$ (Declaration). The Declaration's only purpose is to call for the creation of a Work Programme defining the issues related to global ecommerce that will be discussed. The Work Programme was adopted in September 1998.

The Work Programme on Electronic Commerce defines e-commerce as "the production, distribution, marketing, sale or delivery of goods and services by electronic means." It also divided the scope of the subject among the different WTO Councils. ${ }^{66}$

The Declaration initiated discussion in the WTO General Council to establish a comprehensive work programme to examine all trade-related issues arising from global ecommerce. By 1998, the WTO had initiated discussions on issues of e-commerce and trade by the Trade in Goods; Trade in Services; TRIPS Councils and the Trade and Development Committee. In the meantime, WTO members also agreed to continue their

\footnotetext{
63 The IGF is new international organisation in the UN system created by the World Summit on the Information Society (WSIS). It deals with internet governance issues. See The Internet Governance Forum's Official Website: < http://www.intgovforum.org/>

${ }^{64}$ Helfer, L.R., "Regime Shifting: The TRIPS Agreement and New Dynamics of International Intellectual Property Lawmaking" (2004), 29(1) Yale Journal of International Law 84.

${ }^{65}$ WTO, Ministerial Declaration on Global Electronic Commerce (20 May 1998):

<http://www.wto.org/English/tratop_e/ecom_e/mindec1_e.htm>

${ }^{66}$ These are the Council of TRIPS, the Council for Trade in Services and the Council for Trade in Goods.
} 
current practice of not imposing customs duties on electronic transmissions. This is the practice that stands at the moment of writing. ${ }^{67}$

Given e-commerce is being treated as an issue of trade in services, it is considered an issue for the General Agreement on Trade in Services (GATS). This agreement is based roughly on the same governing principles of the WTO. It also deals specifically with other service-related issues, such as assistance to developing countries in the development of trade issues, monopolies, international payment systems and service trade integration. Interestingly, GATS does not deal with some very important international services, such as labour integration, air and maritime transport, financial services and telecommunications. GATS operates on different service modes, with specific rules for each one. These modes are:

- (“Mode 1") Cross Border Supply: where a service is supplied in a foreign country without either party travelling;

- (“Mode 2") Consumption Abroad: where a service is supplied to a customer who travelled to the service provider's country;

- ("Mode 3") Commercial Presence: where the service is supplied by a locally established foreign entity such as a branch office or subsidiary; and

- ("Mode 4") Presence of Natural Persons: where an individual travels to a foreign country to perform a service while in that country.

International e-commerce would generally be considered under Mode 1 provision of services. Within the context of the above, and of the wider framework of international trade law, numerous questions arise:

- does e-commerce fit within GATT, GATS, or both agreements?

- Are digitisable products goods or services?

- How do trade policies involving e-commerce fit within the policy of technology neutrality in the WTO?

- Is an internet transaction Mode 1 (cross-border supply) or Mode 2 (consumption abroad) within GATS?

- How does 'likeness' ('like services') fit in with providing e-commerce services? Does this conflict with policy of technology neutrality?

- In particular to telecoms and ISP issues, what are the competition law aspects and how do they fit in with GATT and GATS? And,

- What is the relationship between e-commerce and MFN and national treatment obligations? ${ }^{68}$

The DR-CAFTA agreement attempts to answer some of these questions specifically.

\footnotetext{
${ }^{67}$ For some latest reports on the status of electronic commerce at WTO level see WTO documents WT/GC/W/555 (<http://docsonline.wto.org/DDFDocuments/t/wt/gc/w555.doc>) and WT/GC/W/556 (<http://docsonline.wto.org/DDFDocuments/t/WT/GC/W556.doc $>$ ).

${ }^{68}$ See generally Mitchell, A.D., “Towards Compatibility: The Future of Electronic Commerce within the Global Trading System” (2001), J. Int’l Econ. L. 683-723.
} 
Article 14.3 of DR-CAFTA addresses the problem of categorising digital products. 14.3.1 states that there should not be any 'customs duties, fees, or other charges' for importing or exporting digital products by electronic transmission. Thus e-commerce retailers that provide their product over the internet, such as offering software downloads, should not encounter any customs duties for their product.

When digital products are physically shipped across borders, Article 14.3.2 provides that the applicable customs duties must be based on the 'carrier medium' of the product rather than the value of the digital product contained on the medium (such as the plastic CD rather than the music contained on it).

Article 14.3.3 accords national treatment standards (under the 'no less favourable treatment' formula) to digital products transmitted electronically for 'like' products and when the digital products are created by a non-party. Thus even authors and distributors from non-Parties to the agreement can expect equal treatment for digital products.

The trade in electronically delivered digital products is a new and complex issue at the level of international trade; one that wasn't really present at the inception of the WTO in 1995. A recent book, Sacha Wunsch-Vincent's The WTO, The Internet, and Trade in Digital Products clarifies the legal setting and negotiation possibilities in this area. This book is limited to the issues surrounding the delivery of digital content over the internet. ${ }^{69}$ Of particular interest is Chapter 7, which discusses digital products and regionalism. Wunsch-Vincent notes that the US-Chile and US-Singapore FTAs were the first trade agreements to include separate e-commerce chapters and complementary GATS-plus provisions related to digital products. ${ }^{70}$ The United States later used these agreements as a blueprint for later FTAs, including the negotiations for CAFTA. ${ }^{71} \mathrm{He}$ goes on to put US strategies on e-commerce in bilateral and multilateral treaties within the context of world trade policy and agreements, and his work should be consulted for further detail.

Wunsch-Vincent starts out the book by noting that 'due to the novel character of these digital trade flows, no academic contribution exists that comprehensively lays out the necessary steps that WTO members must take to remedy [the lack of treatment of ecommerce issues in international trade law]'. ${ }^{72}$ Though his book goes a long way towards addressing e-commerce and trade issues, there appears to exist a gap in the literature in regards to the broader e-commerce issues mentioned above, such as data privacy and cyber security, and jurisdictional issues, and how they fit (or could fit) into the WTO/FTA framework (if at all). This could be an area of potential fruitful collaborative study between international trade lawyers, IT lawyers, and economists.

Perhaps the nature of the issue left out of these agreements leaves the only option as the one that they chose in DR-CAFTA. In Article 14.5 the Parties agree simply to work

\footnotetext{
${ }^{69}$ Wunsch-Vincent, S., The WTO, The Internet and Trade in Digital Products (2006), p.2.

${ }^{70}$ Ibid., p.202-3.

${ }^{71}$ Ibid., p.203.

${ }^{72}$ Ibid., p.1.
} 
together and share 'information and experiences on laws, regulations, and programs in the sphere of electronic commerce'. Further collaborative research is needed to identify if this is so.

\subsection{Other aspects of e-commerce in Latin America}

To look only at the narrow band of what is specifically addressed in FTAs is to miss many of the issues confronted by e-commerce businesses on the ground in these countries. A survey of the available academic literature identified the following sociocultural differences in Latin America that e-commerce businesses may face:

- Latin Americans generally prefer shopping in person; ${ }^{73}$

- Latin Americans on the whole lack credit cards to buy goods over the internet; ${ }^{74}$

- those that have credit cards do not trust internet transactions nor like over-thephone payments; ${ }^{75}$ and

- 'Latin America' is not one single region, but a group of countries that speak different dialects of one language (Spanish) or speak other languages (such as Portuguese) and have different cultural traditions. ${ }^{76}$ This is an issue that, of course, other regional groups such as the European Union have faced.

Dealing with these types of issues seems to be too region specific to be dealt with at the high level of a multi-lateral FTA. Some issues, like the different dialects of Spanish, are simply realities of business in the region and not issues appropriate for FTAs. Others, such as the level of consumer trust for internet credit card transactions, seem too regionspecific to address in a FTA, though it is certainly worthy of investigation.

Nagle, writing in 2001, also identified other issues tied into expanding e-commerce in the region:

- low rates of computer ownership; ${ }^{77}$ and

- logistical barriers in getting products ordered electronically to consumers, such as shipping infrastructure (roads, communication, rail, and other facilities) as well as difficulties in dealing with customs authorities. ${ }^{78}$

The increased development and economic prosperity that is the goal of FTAs such as DRCAFTA, if effective, would have the most impact on these two issues. As noted above, we make no analysis on the general effectiveness of FTAs at economic development, but it is important to keep in mind how other factors can directly affect e-commerce within the region.

\footnotetext{
73 Nagle, L.E., "E-Commerce in Latin America: Legal and Business Challenges for Developing Enterprise” (2001), 50 Am. U. L. Rev. 859, p.871.

${ }^{74}$ Ibid., p.869.

75 Ibid., p.907.

${ }^{76}$ Ibid., p.867.

${ }^{77}$ Ibid., p.873

${ }^{78}$ Ibid., p.896.
} 


\subsection{Institutional legal challenges to e-commerce}

Commentators have also identified institutional legal issues confronting the expansion of e-commerce within Latin America:

- judges can't perhaps be as fluid about the law in the civil law systems so there may be unpredictable results;

- overtly formal nature of legal systems cause delay;

- lack of willingness to regulate on the part of the government bodies that govern regulated industries creates too much risk;

- admissibility of electronic records; and

- requirement of formalities in contract and their application to e-contracts. ${ }^{79}$

These institutional issues could perhaps be addressed by general obligations to ease the burden of formal measures for conducting business, such as transnational shipping, in the region. Specific obligations carefully tailored to the precise obstacles could potentially be a part of an FTA.

\subsection{US e-commerce agenda}

The Bipartisan Trade Promotion Authority Act of 2002, which granted the executive the authority to 'fast track' trade agreements, states the following as goals of use of the authority:

\section{“(9) Electronic commerce}

The principal negotiating objectives of the United States with respect to electronic commerce are-

(A) to ensure that current obligations, rules, disciplines, and commitments under the World Trade Organization apply to electronic commerce;

(B) to ensure that-

(i) electronically delivered goods and services receive no less favorable treatment under trade rules and commitments than like products delivered in physical form; and

(ii) the classification of such goods and services ensures the most liberal trade treatment possible;

(C) to ensure that governments refrain from implementing trade-related measures that impede electronic commerce;

(D) where legitimate policy objectives require domestic regulations that affect electronic commerce, to obtain commitments that any such regulations are the least restrictive on trade, non-discriminatory, and transparent, and promote an open market environment; and

(E) to extend the moratorium of the World Trade Organization on duties on electronic transmissions." ${ }^{80}$

\footnotetext{
${ }^{79}$ Ibid., pp.892-916.
}

${ }^{80} 19$ USC 3802 (b)(9) 
These stated goals are straightforward, and may serve to indicate the relative inactivity in the discussion of trade-related issues of e-commerce at the international level. It is clear from the above that the United States is content with current practices at the WTO, and therefore there is an effort to maintain the status quo.

\subsection{Future activities}

Within the legal academic community, it does not appear that there has been much focus on e-commerce per se in Latin America since 2001-2002 in international law journals. It must be noted that as researchers in the e-commerce field, there appears to be a general decline in e-commerce focused articles and research since this time - possibly in relation to the dotcom crash that occurred during that time. As mentioned above, within the trade law context, there exists a significant gap regarding the potential to address wider ecommerce issues within trade agreements. Collected at the end of the report is a selected list of relevant articles, publications and websites that may be of interest to start out research in this area.

Further work could be carried out with greater in-depth analysis of specific issues, such as the state of electronic contracts or digital signatures in DR-CAFTA member countries. These results could then be fed into a study on the possibility of greater regional harmonisation of these topics, and whether this harmonisation can be carried out at the FTA level or some other regional agreement.

\subsection{Intermediary liability}

One of the biggest legal issues to come out the development of the internet is the problem of intermediary liability. The internet essentially consists of a wide variety of entities (commercial and non-commercial, corporate and individual) providing connections or other services between point A and point B. Because some of the traffic flowing over these connections can give rise to legal liability (both civil and criminal), the question has arisen as to the role of these intermediaries. Reed identifies three common themes of intermediary liability. The first two, he notes are nearly universal, with the last only implemented in a few legal systems. They are:

1. if the intermediary knows or has reason to know that the content is unlawful;

2. irrespective of knowledge, if the intermediary directly benefits; and

3. if the intermediary doesn't take reasonable steps to determine the lawfulness of the content. ${ }^{81}$

The problem of intermediary liability within the internet context generally is that providers of access to the internet are by nature intermediaries, and that it is difficult to control what happens on or through their networks. If every act by a subscriber opened them up to liability, there would be little reason to offer the services. How intermediaries are held liable for content, as well as how they are granted immunity from that liability, is a question largely dependent on the specifics of each countries legal system, and thus

${ }^{81}$ Reed, C., Internet Law: Text and Materials (2004), p.121. 
outside the scope of this project. Because the DR-CAFTA agreement essentially requires partners to import the US model of liability, we focus on arguments centred on this model and its inclusion into the agreement.

\subsection{What DR-CAFTA requires}

The DR-CAFTA agreement contains requirements for intermediary liability for copyright infringement in Article 15.11.27, and is closely modelled on US liability provisions outlined in the Digital Millennium Copyright Act (DMCA) in 17 U.S.C. s.512. The DRCAFTA article breaks down into two sections. Section 15.11.27(a) requires that parties provide 'legal incentives' so that service providers will work with copyright owners in deterring copyright infringement over their networks. The more substantive s.15.11.27(b) outlines specific limitations in liability that must be enacted, and it is this section that we will concentrate our analysis.

\subsection{Who is covered and for what}

The definition of service provider contained in DR-CAFTA almost exactly tracks the language in the US DMCA, and provides for two different kinds of service providers under the liability provisions - those who only move content along their networks (transmission, routing, and 'connections for digital on-line communications') and anyone else who provides or operates 'facilities for on-line services or network access' ${ }^{82}$

Starting with this definition in mind is important when doing comparative work in this area - the EC Copyright Directive, ${ }^{83}$ for example, takes a different approach in respect of who will qualify for protection. ${ }^{84}$ In addition, the DMCA and the DR-CAFTA importing obligation only grants limitations on liability for copyright, not all content. However, it should be borne in mind that other areas of the law, most notably defamation, play a role in issues of intermediary liability on the internet.

\subsection{Limits on liability}

The ISP immunity provisions in DR-CAFTA do primarily two things:

1. the agreement provides limits on copyright liability for ISPs who meet certain procedural requirements in four areas. These areas are known as the 'safe harbours' both in the DR-CAFTA agreement and in the DMCA; and

2. the agreement requires ISPs to give identifying information about their subscribers once they have received a subpoena alleging copyright infringement.

\footnotetext{
${ }^{82}$ Digital Millennium Copyright Act (DMCA), 17 U.S.C, s.15.11.27 (b)(xii)

${ }^{83}$ Directive 2001/29/EC of the European Parliament and of the Council of 22 May 2001, on the harmonization of certain aspects of copyright and related rights in the information society: <http://eurlex.europa.eu/LexUriServ/site/en/oj/2001/1_167/1_16720010622en00100019.pdf>

${ }^{84}$ For more on this, see Edwards, L. \& Waelde, C., Online Intermediaries and Copyright Infringement (April 18, 2005), WIPO/IIS/05/1.
} 
As mentioned, the DMCA only limits liability for certain activities known as the 'safe harbours'. They are:

1. transmitting, routing, or providing connections for material (DRCAFTA 15.11.27 (b)(i)(A); DMCA 512(a));

2. $\quad$ automated caching (DRCAFTA 15.11.27 (b)(i)(B); DMCA 512(b));

3. storage at the user's direction (DRCAFTA 15.11.27 (b)(i)(C); DMCA 512(c)); and

4. referring or linking (DRCAFTA 15.11.27 (b)(i)(D); DMCA 512(d)).

The liability granted limits relief to non-monetary measures and further limits relief to 'compel or restrain' ISPs to engage in particular actions to 'reasonable restrictions'. ${ }^{85}$

\subsection{Arguments for use of the DMCA model}

US rights holders argue that the inclusion of ISP liability provisions similar to the DMCA are necessary under Article 41 of TRIPs in order to 'effective action against any act of infringement of intellectual property rights covered by this Agreement, including expeditious remedies to prevent infringements and remedies which constitute a deterrent to further infringements. ${ }^{86}$ This is an argument put forward most often by the International Intellectual Property Alliance (IIPA) ${ }^{87}$ in their critiques of IP systems for the US 301 process considered above (with the goal of placing offending nations on a watch list). ${ }^{88}$ In comparison with DR-CAFTA, the Australian-US FTA explicitly lays out that the purpose of the ISP liability section is to comply with Article 41 of TRIPs. ${ }^{89}$

\subsection{Arguments against use of the DMCA model}

Hinze, in a 'Briefing Paper' produced by the Electronic Frontier Foundation, outlines several arguments against exporting the DMCA system of intermediary liability which are referenced below. ${ }^{90}$

Exporting US ISP liability rules may actually create liability where none previously existed. Rules on contributory and vicarious infringement, which the DMCA intermediary liability language is meant to address, are not the same in all legal systems. There are no international agreements or standards in this area of copyright law, and as a result, service providers in many legal systems are not liable for copyright infringement for the activities this provision covers. By introducing exemptions from liability into these systems, this could create a legal basis for implying liability in these systems. ${ }^{91}$

${ }^{85}$ DMCA, supra. 76, s.15.11.27(b)(i).

${ }^{86}$ TRIPS, supra. 24.

${ }^{87}$ International Intellectual Property Alliance: $<$ http://www.iipa.com/>

${ }^{88}$ E.g. South Africa: <http://www.iipa.com/rbc/2002/2002SPEC301SOUTHAFRICA.pdf>

${ }^{89}$ Australia-US Free Trade Agreement (January 1, 2005), Article 17.11.29:

$<$ http://www.dfat.gov.au/trade/negotiations/us_fta/final-text/index.html>,

${ }^{90}$ Hinze, G., Briefing Paper: Internet Service Provider Safe Harbors and Expedited Subpoena Process in the U.S. Digital Millennium Copyright Act and Recent Bilateral Free Trade Agreements:

$<$ http://www.eff.org/IP/FTAA/ISP_june05.pdf>

${ }^{91}$ Ibid., p.3. 
The US model of notice and takedown 'is particularly susceptible to abuse' and has little benefit when weighed against the costs (financial and otherwise). ${ }^{\mathbf{9}}$ The main argument centres upon the structure of the law as a tool 'by private parties to censor legitimate criticism'. The paper discusses the high profile Diebold case in the United States, whereby an electronic voting machine manufacturer used the DMCA and copyright law to prevent discussion about flaws in its e-voting products. ${ }^{93}$ Because the provisions outlined for immunity give an incentive to ISPs to 'take down first, and ask questions (if at all) later', controversial material is susceptible to being removed from the web, contrary to freedom of speech. In addition, the notice-and-take-down process outlined in the law has been automated, enabling copyright owners to send tens of thousands of notices with only a minimum of investigation. Finally the counter-notice process outlined in the agreement requires that the counter-notifier 'consent to the jurisdiction of the courts of the Party', 94 a provision that discourages use of the process and thus preservation of material online in the face of a weak or non-existent infringement claim.

The provisions do not account for current net architecture and are not flexible enough to deal with new technologies. This argument centres upon peer-to-peer networks, which were not in widespread use at the time of DMCA's writing, and their application to these provisions. In short, because of the distributed topology of these networks, the DMCA has been used in the United States to send arguably invalid takedown notices for content that does not reside on the ISP's network. ${ }^{95}$

The provisions could be used to terminate internet access based on a single allegation of infringement. Content owners have used the requirements for ISPs to maintain a policy on 'repeat infringers ${ }^{96}$ to send 'termination notices' that request the termination of a users' internet account on the basis of a single allegation of infringement. It is argued that this threatens access to the internet, especially if automated processes are used ('bots') to send out these 'termination notices'. ${ }^{97}$

In addition to the above, Hinze has covered the problems with the expedited subpoena process in the United States. The US has implemented the subpoena procedure as an administrative measure, without the intervention of full judicial process. The DR-CAFTA agreement, as well as other FTAs with similar provisions, leave open the possibility of a full judicial process for these subpoenas. She cautions the following for countries adopting an administrative process. ${ }^{98}$

The resulting process in the US may increase ISP liability and has put privacy at risk because it has devolved into automated disclosure of identity that circumvents

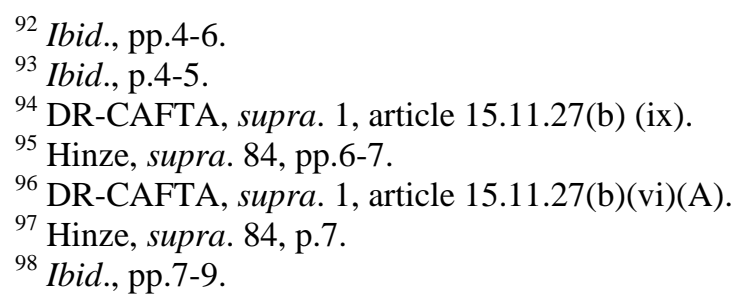


established judicial review. ISPs are not required to notify their customers that their identity has been requested, and there is no formal right by the subscriber to oppose the disclosure of their information. If there is a case of mistaken identity, the subscriber may have no recourse to other action against the ISP or the copyright holder, or in the alternative, the ISP may be subject to suit for disclosing the wrong information. In addition, copyright owners can use the process simply to identify people without an intent to file a suit. ${ }^{99}$

Increased costs to ISPs. The expedited process encourages requests, and as a result ISPs may face large numbers of requests thus necessitating increased legal costs and employee time. ${ }^{100}$

\subsection{Further activities}

As the agreement is in force and adopted by all DR-CAFTA parties save Costa Rica (with approval expected soon), further research will most likely need to focus on ex post factors and comparison. One exception is, as mentioned above, Costa Rica. Under the terms of DR-CAFTA, if approved, Costa Rica has 30 months after ratification to implement the intermediary liability provisions. ${ }^{101}$ Work on how to implement the ISP liability provision under Costa Rican law could be beneficial, notably in clarifying difficulties identified within the DMCA.

Unlike with exporting the anti-circumvention provisions in the DMCA, little research has been done in English-language law journals addressing the exportation of DMCA intermediary liability standards. There exists an extensive amount of academic work on intermediary liability in relation to the DMCA provisions in the United States, and any further study into the application of the above provisions in the DR-CAFTA parties will benefit from this material. Despite being 'locked in' to the approach to intermediary liability outlined in DR-CAFTA, comparative analysis with EC laws on intermediary liability would be of benefit. It would also be interesting to consider and compare different models of liability in areas of content liability other than copyright.

More work is needed in this area, preferably with the following goals in mind:

1. For countries in the process of negotiating FTAs with the United States, or considering them in the future, tools to use when considering the intermediary liability provisions.

2. For countries that have already concluded FTAs with the United States with similar provisions, country-specific analysis of the obligations in the agreement with a view to exploiting any flexibilities, such as requiring judicial process for the subpoena process.

3. Bigger picture analysis about the impact on the inclusion of these standards on questions of internet governance.

\footnotetext{
${ }^{99}$ Ibid., pp.8-9.

${ }^{100}$ Ibid., p.7 \& p.9.

${ }^{101}$ DR-CAFTA, supra. 1, Article 15.12.2(a).
} 
4. Quantitative and qualitative study of the impact of these provisions on service providers, with a specific focus on the costs of compliance with these provisions and their effect on the availability of service.

As to the last recommendation, it should be noted that the original DMCA provisions concerning intermediary liability were an attempt by the US ISP industry to address liability under specific US case law. ISP reaction to new liability rules in the participating DR-CAFTA countries could be very indicative of the landscape of liability, as well as the business climate for ISPs in these countries. At first instance, a qualitative study could address this gap in the research. It could then be followed up with quantitative research into the use of the new intermediary liability provisions.

\subsection{IP More Generally}

IP laws can have broader impact on IT-based businesses, especially in relation to liability for acts in the online environment. As such we have included this brief overview, and cover in the report the following:

- UDRP for ccTLDs (section 10.0);

- anti-circumvention law (section 9.1);

- pre-established damages and copyright (section 11); and

- intermediary liability and copyright (section 8).

The DR-CAFTA agreement, much like TRIPS, sets a series of minimum standards (article 15.1.1) and national treatment (article 15.1.8). ${ }^{102}$ The agreement includes an affirmation of each party's rights and obligations under TRIPS and the WIPOadministered IPR treaties.

\subsection{Areas of IP covered by DR-CAFTA}

The DR-CAFTA agreement covers many areas of IP, including areas that might not strictly be 'IP' but are highly related. This includes:

- $\quad$ patents (15.9 and 15.10);

- $\quad$ copyright (15.5 to 15.8$)$;

- $\quad$ trade marks (15.2 and 15.4);

- geographical indications of origin (15.3 and 3.12);

- domestic content restrictions (10.9.1(f));

- $\quad$ satellite signals (15.8); and

- $\quad$ patents and public health issues $(9.9,10.7 .5,10.9 .3(\mathrm{~b})$, and letter of understanding on 5 August 2004.).

102 There are some exceptions to national treatment for designated agent for service of process (article 15.1.9) and procedures under WIPO IPR treaties (article 15.10). 
The agreement covers many of these areas directly, but also sets standards by including requirements to accede or make efforts to accede to other treaties related to intellectual property. DR-CAFTA requires its members to ratify the following IP treaties:

- WIPO Copyright Treaty (WCT) (1996);

- WIPO Performances and Phonograms Treaty (WPPT) (1996);

- Patent Cooperation Treaty as revised and amended (PCT) (1970);

- Budapest Treaty on the International Recognition of the Deposit of Microorganisms for the Purposes of Patent Procedure (1980);

- Convention Relating to the Distribution of Programme-Carrying Signals Transmitted by Satellite (1974); and

- Trademark Law Treaty (TLT) (1994). ${ }^{103}$

The International Convention for the Protection of New Varieties of Plants (UPOV 1991) is required unless the party offers 'effective patent protection for plants', in which case they are required to make 'all reasonable efforts to ratify or accede to the UPOV Convention'. ${ }^{104}$

The following treaties are not mandatory, but parties 'shall make all reasonable efforts to ratify or accede to' the:

- $\quad$ Patent Law Treaty (PLT) (2000);

- Hague Agreement Concerning the International Registration of Industrial Designs (1999); and

- Protocol Relating to the Madrid Agreement Concerning the International Registration of Marks (Madrid protocol) (1989).

It should also be noted that all DR-CAFTA countries are already members of TRIPS, and therefore faced with existing significant IP obligations. As well as specific standards, TRIPS also incorporates, and makes mandatory for the first time, includes obligations under other IP treaties, notably the Berne (copyright) and Paris (industrial property) Conventions. However, the requirements of DR-CAFTA appear to have some impact on accession to these other IP treaties: ${ }^{105}$ Guatemala, for example, joined the Patent Cooperation Treaty on 14 October 2006, and the Dominican Republic joined in 2007. Further developments and impacts will be interesting to observe.

Out of these required treaties, of particular relevance are the two WIPO Internet Treaties, the WCT and WPPT, and their requirements for the legal protection of technical protection measures (TPMs) and rights management information. As is seen from the table below, however, only the Dominican Republic had not already had both treaties enter into force before the signing of the DR-CAFTA. The requirements of these treaties

\footnotetext{
103 Articles 15.2 - 15.4.

${ }^{104}$ Article 15.5 (a-b).

${ }^{105}$ WIPO.int: <http://wipo.int/treaties/en/Remarks.jsp?cnty_id=1936C>; Accession dates and membership of the above-mentioned treaties is available on the WIPO site and should be consulted for reference to membership dates of the various treaties mentioned.
} 
and of the DR-CAFTA agreement in relation to TPMs is addressed further in the Anticircumvention section below.

\begin{tabular}{|l|l|l|}
\cline { 2 - 3 } \multicolumn{1}{c|}{} & \multicolumn{2}{c|}{ Date of Entry into Force } \\
\hline DR-CAFTA party & WCT & WPPT \\
\hline Costa Rica & 6 March 2002 & 20 May 2002 \\
\hline Dominican Republic & 10 January 2006 & 10 January 2006 \\
\hline El Salvador & 6 March 2002 & 20 May 2002 \\
\hline Guatemala & 4 February 2003 & 8 January 2003 \\
\hline Honduras & 20 May 2002 & 20 May 2002 \\
\hline Nicaragua & 6 March 2003 & 6 March 2003 \\
\hline United States & 6 March 2002 & 20 May 2002 \\
\hline
\end{tabular}

\subsection{Trade Promotion Authority objectives}

As has been seen, many of the DR-CAFTA standards closely reflect provisions in US law, in light of the objectives of the President's power under the Trade Promotion Authority. In respect of IP, this authority should be used for:

- ensuring that the provisions of any multilateral or bilateral trade agreement governing intellectual property rights that is entered into by the United States reflect a standard of protection similar to that found in United States law; ${ }^{106}$

- $\quad$ providing strong protection for new and emerging technologies and new methods of transmitting and distributing products embodying intellectual property; ${ }^{107}$ and

- ensuring that standards of protection and enforcement keep pace with technological developments, and in particular ensuring that rights holders have the legal and technological means to control the use of their works through the Internet and other global communication media, and to prevent the unauthorized use of their works. ${ }^{108}$

As has been seen above, the USTR has accomplished this goal by at times copying US statutes almost verbatim for their inclusion in FTAs, specifically the Digital Millennium Copyright Act (DMCA), which is discussed in the anti-circumvention and intermediary liability sections.

\subsection{UDRP and FTAs}

DR-CAFTA considers trade marks in some detail. ${ }^{109}$ Article 15.2.1, for example, defines what marks are required (e.g. sound marks), and what marks are optional (e.g. scent marks). Such issues as trade mark 'fair use' (article 15.2.4), recordal of licences (article 15.2.10), term of initial registration (article 15.2.9 - ten years) and well known marks under the Paris Convention article 6bis (article 15.2.5) are included. All of the trade mark

\footnotetext{
${ }^{106}$ US Trade Promotion Authority Act, s. 2(b)(4)(A)(i)(II)

${ }^{107}$ Ibid., s. 2(b)(4)(A)(ii)

${ }^{108}$ Ibid., s. 2(b)(4)(A)(iv)

${ }^{109}$ See DR-CAFTA, supra. 1, article 15.2.
} 
requirements could potentially impact IT-based businesses as businesses (particularly sound marks, and well known marks). However, we confine our analysis to the more ITrelated requirements in DR-CAFTA regarding dispute resolution for domain names (article 15.4.1) ${ }^{110}$ and a WHOIS database (article 15.4.2).

Domain names are not trade marks. However, the Uniform Domain Name Dispute Resolution Policy (UDRP) is a dispute resolution policy governing domain name disputes based on existing trade mark ownership. It was created by the Internet Corporation for Assigned Names and Numbers (ICANN) based on a US Government White Paper and WIPO's subsequent report, both on the issue of trade marks and domain names. ${ }^{111}$ The UDRP is only a means of dispute resolution. Decisions are made by accredited dispute resolution service providers. At the time of writing these are the Asian Domain Name Dispute Resolution Centre, the National Arbitration Forum and the World Intellectual Property Organization. ${ }^{112}$

The UDRP governs disputes over domain names for Top Level Domains (TLDs) controlled by ICANN; namely, the generic Top Level Domains (gTLDs) such as '.com' and '.net'. In addition to these more familiar domain names, each country gets a two letter TLD assigned to it known as a country-code TLD (ccTLD), such as '.cr' for Costa Rica, and ‘.uk’ for United Kingdom. Individual countries have control over the use of these ccTLDs, including the dispute resolution policies (if any) over the use of trade marks in these names. It is this question of dispute resolution for ccTLDs of DR-CAFTA countries that is considered here.

\subsection{The design of the UDRP system}

The UDRP includes a contract, essentially an agreement to arbitrate in respect of disputes over the domain name. This must be signed by everyone that wishes to register a domain name. In the case of gTLDs, ICANN requires all registrars who wish to receive the right to register domain names in the gTLD namespace to include the UDRP into each registration agreement.

The operators of other TLDs, such as the ccTLDs mentioned above, can decide whether or not to follow the UDRP. As noted below, some follow this policy and require all registrants to adhere to the UDRP and others have designed their own dispute resolution policies. $^{113}$

\footnotetext{
${ }^{110}$ Additional information on dispute resolution for domain names is provided in Annex B of the Research Appendix to this report.

${ }^{111}$ ICANN, Timeline for the formulation and implementation of the Uniform Domain-Name DisputeResolution Policy: <http://www.icann.org/udrp/udrp-schedule.htm>

112 ICANN, Approved Providers for the Uniform Domain-Name Dispute-Resolution Policy: $<$ http://www.icann.org/dndr/udrp/approved-providers.htm>

${ }^{113}$ E.g. Nominet (UK): <http://www.nominet.org.uk/disputes/drs/policy/?contentId=3069>
} 


\subsubsection{UDRP disputes}

The UDRP is designed to address clear cases of cybersquatting. Because domain names must be unique - there can only be one 'coke.com' - you can imagine that trade marks often prominently feature in disputes over domain names. Domain name registration was initially done on a 'first come first served' basis. This led to a number of people registering known trade marks (or variations of them) as domain names with the intent of selling the domain name to the registered owner for a profit. This practice came to be known as "cybersquatting". 114

\subsubsection{The place of national law}

The UDRP (Paragraph 4) requires a domain name holder to submit to a mandatory administrative proceeding in the event that a third party asserts that:

1. the domain name is identical or confusingly similar to a trademark or service mark in which the complainant has rights; and

2. the domain name holder has no rights or legitimate interests in respect of the domain name; and

3. the domain name has been registered and is being used in bad faith.

Paragraph 4.k however makes it quite clear that either the domain name holder or the complainant may submit the dispute to a national court either before the mandatory administrative proceeding is commenced or after it is concluded. After conclusion of the administrative proceedings, and if the administrative panel decides that the domain name registration should be cancelled or transferred, the domain name holder has 10 business days to file a law suit and furnish evidence to the Panel. If evidence is furnished, then the Panel will take no further action until such time as it receives evidence that the matter has been settled or withdrawn. As national laws and courts continue to address domain name questions, this is an important provision. ${ }^{115}$

\subsection{DR-CAFTA and the UDRP}

DR-CAFTA in Article 15.4 under the heading "Domain Names on the Internet" requires that the parties provide, for their respective ccTLDs:

"an appropriate procedure for the settlement of disputes based on the principles established in the Uniform Domain-Name Dispute Resolution Policy.”

\footnotetext{
${ }^{114}$ For an early analysis see Waelde, C., “Trade Marks and Domain Names: There's a lot in a name”, in: Edwards, L. \& Waelde, C. (eds), Law and the Internet: Regulating Cyberspace (2000).

${ }^{115}$ See Dinwoodie, G., “Ten Years of Trademark Law: Lessons for the Future?” in: Hansen, H. (ed), International Intellectual Property Law and Policy (2003), p.8: in particular the section 'Extending domestic law internationally'. Article can be found at:

$<$ http://www.kentlaw.edu/depts/ipp/publications/tenyearsoftmlaw.pdf>. See also Societe Gervais Danone $v$ Societe le Reseau Voltaire [2003] E.T.M.R 26.
} 
Thus the DR-CAFTA parties will be required to model their domain name dispute settlement procedures along the lines of the UDRP. This 'UDRP-like' requirement is not unique to the DR-CAFTA, and a sampling of other FTAs has revealed its inclusion elsewhere:

- Chile-US has a UDRP requirement in Article 17.3;

- Singapore-US in Article 16.3; and

- Australia-US in Article 17.3.

From the perspective of the greater political context of US strategies towards the Americas, the UDRP was a requirement in drafts of the previously-mentioned FTAA. ${ }^{116}$ Efforts to include this requirement in the various FTAs the United States is negotiating in the region could be seen as an effort to achieve piecemeal what could not be done via the FTAA.

The standard outlined in the treaty of having a policy based on the principles of the UDRP at first instance seems to grant wide latitude. However, any study of the implications of these provisions would by necessity need to address just what these principles were likely to be, so as to assess compliance. DR-CAFTA, as well as other FTAs having similar provisions, provide for dispute resolution procedures to enforce the agreement. ${ }^{117}$ This could provide for some incentive to interpret the 'principles' as close as possible to the text of the UDPR, and also with wide interpretations of 'bad faith' and narrow interpretations of 'legitimate interests' (paragraphs 4(ii) a d (iii) respectively).

\subsection{Use of the UDRP by ccTLDs}

A full review of the policies of each of the ccTLD registrars is outside of the scope of this project, but needless to say, the UDRP has been accepted by many ccTLD operators. Bettinger et al. ${ }^{118}$ review the use of the UDRP by ccTLDs, and bases his finding on the number of ccTLDs that refer to the WIPO Arbitration Center (one of the UDRP providers) as a dispute resolution provider. Using this relatively simple rubric, at the time of this writing, there are 47 ccTLDs that use WIPO as a provider. ${ }^{119}$ To get an idea of the scope, there are a total of 243 ccTLDs, though not all get used. ${ }^{120} \mathrm{~A}$ list of the ccTLDs and their administrators is available. ${ }^{121}$

\footnotetext{
${ }^{116}$ FTAA draft agreements are available from:

<http://www.sice.oas.org/TPD/FTAA/FTAA_e.ASP\#DraftTexts>

${ }^{117}$ DR-CAFTA, supra. 1, Chapter 20.

${ }^{118}$ Bettinger, T., Willoughby, T. \& Abel, S.M., Domain Name Law and Practice : An International Handbook, (2005).

${ }^{119}$ This unit of measurement is not the most accurate as, for example, the United States uses the UDRP for its '.us' domain, but does not have WIPO as a provider for disputes under this agreement. Abel, S.M., “United States of America” in: Bettinger, Willoughby \& Abel, supra. 11, pp.889-925.

${ }^{120}$ See for example .gb, which is no longer in use but is run by JANET: < http://www.iana.org/rootwhois/gb.htm>

${ }^{121}$ Iana, Root-Zone Whois Information: <http://www.iana.org/root-whois/index.html>; For a review of ccTLDs and in-depth analysis of several countries’ domain name systems see Bettinger, Willoughby \& Abel, supra. 11.
} 
Several commentators in the region are concerned about the potential impact of the inclusion of 'UDRP-like' clauses for the agreement's signatory states. Costa Rican IT Law expert Christian Hess points out that there is an inherent danger in adopting a system which practically forces member states to use the UDRP as the sole method of dispute settlement, because the system seems to be skewed towards the protection of commercial interests. $^{122}$

Do the other signatory states accommodate the UDRP-like requirement? Guatemala lists WIPO as a dispute resolution provider and notes that it follows the UDRP procedure ${ }^{123}$ and, therefore, would seem to comply. Similarly, Nicaragua's ccTLD registrar specifically states that it complies with the UDRP ${ }^{124}$. A cursory look at the dispute settlement provisions of each of the ccTLD registrars would seem to indicate that Dominican Republic, Honduras, El Salvador and Costa Rica lack “appropriate procedures" in the sense of Art $15.4^{125}$. To illustrate this one might consider that the list of principles for withdrawal of domain name registration maintained by the Costa Rican national registrar (NIC-Costa Rica). ${ }^{126}$ None of the principles are up to the UDRP's standards, as the most substantive sanction is through inappropriate or illicit use of a domain name ${ }^{127}$.

\subsection{UDRP Criticisms}

The UDRP has been the subject of much criticism within the legal and academic communities, and that literature should be consulted to review the controversy over the system. ${ }^{128}$ The chief criticism that has arisen is that, as noted above, the UDRP dispute process tilts towards trade mark holders and those with more resources to fight domain name disputes, even against arguably legitimate owners in the case of "reverse domain name hijacking". ${ }^{129}$ Notwithstanding apparent safeguards in the UDRP, ${ }^{130}$ there is also concern that use of domain names in critical comment ${ }^{131}$ might be prevented.

\footnotetext{
${ }^{122}$ Hess, C., “TLC, ALCA e Internet” (March 10, 2004), La Nación, p.15:

$<$ http://www.nacion.com/ln_ee/2004/marzo/10/opinion2.html>

${ }^{123}$ WIPO, Domain Name Dispute Resolution Service for .GT:

$<$ http://wipo.int/amc/en/domains/cctld/gt/index.html>

${ }^{124}$ See: Política uniforme de solución de controversias en materia de nombres de dominio (Aug 26, 1999),

Nic.ni: <http://www.nic.ni/index.php?s=2>

125 The relevant policies for each country can be found at the following sites: Dominican Republic

$<$ http://www.nic.do/politica.php3>; Honduras <http://www.nic.hn/politicas/>; El Salvador

$<$ http://www.svnet.org.sv/svpolitica.html>; and Costa Rica <http://www.nic.cr/esp/politicas5.html>.

${ }^{126}$ Regulaciones del NIC en Costa Rica, La Gaceta No.243 del 13 de diciembre del 2004.

127 Ibid., art. 4.

${ }^{128}$ Including comment on the extent to which it is proper and viable to create hybrid forms of dispute resolution, like the UDRP: Helfer, L. \& Dinwoodie G., Designing Non-National

Systems: The Case of the Uniform Domain Name Dispute Resolution Policy::

<http://www.kentlaw.edu/depts/ipp/intl-courts/docs/dh.pdf>

${ }^{129}$ See e.g. Geist, M., Fair.com?: An Examination of the Allegations of Systemic Unfairness in the ICANN UDRP.: <http://aix1.uottawa.ca/ geist/geistudrp.pdf>; Donahey, "The UDRP:

Fundamentally Fair, But Far From Perfect” (2001), 6(34) Electronic Commerce \& Law Reports, available from <http://www.tzmm.com/frames/fartics.htm>; Donahey, Fundamentally Fair.com? An Update on Bias
} 
One further criticism of the UDRP that is of particular relevance to this project is Froomkin's point that official translations of the policy into languages other than English do not exist. ${ }^{132}$

\subsection{WHOIS}

A WHOIS database is a database, maintained by a service provider, that contains the name and contact information of the registrant of a domain name. WHOIS databases are seen as a valuable tool in identifying the owner of potentially infringing domain names and to locate and identify owners for purposes of a law suit over content or actions associated with a particular site. There have been numerous discussions about privacy concerns over the public availability of this information. In addition to privacy concerns, ${ }^{133}$ the availability of this information also can open up individuals to attacks from phishers and other online scammers. Concerns are now well established and often aired in mainstream media. ${ }^{134}$

The DR-CAFTA agreement requires the use of such a database, but allows for provisions dealing with privacy. Article 15.4.2 states

"Each Party shall require that the management of its ccTLD provides on-line public access to a reliable and accurate database of contact information for domain-name registrants. In determining the appropriate contact information, the management of a Party's ccTLD may give due regard to the Party’s laws protecting the privacy of its nationals."

This would seem to allow for some degree of balance, though further research and analysis is needed, including as to how it operates in practice. Some guidance can now be found in ICANN's Whois Task Force Final Task Force Report on Whois Services released on 16 March 2007. ${ }^{135}$

Allegations and the ICANN UDRP.: <http://aix1.uottawa.ca/ geist/fairupdate.pdf $>$; c.f. e.g. decision in Meat and Livestock Commission v Pearce [2004] E.T.M.R. 26

${ }^{130}$ See UDRP, para. 4 (ii) \& (iii).

${ }^{131}$ See UDRP decision Vivendi $v$ Sallen D2001-1121:

<http://www.wipo.int/amc/en/domains/decisions/html/2001/d2001-1121.html>; and McMahon, R., “Certainty Still Some Way Off for Non-Commercial Use of Trade Marks in Domain Names” (2005), 10(5) Comms. L. 153.

${ }^{132}$ Froomkin, A.M., ICANN'S 'Uniform Dispute Resolution Policy' -- Causes and (Partial) Cures (2002) 67 Brook. L. Rev. 605, p707. For further analysis of the potential implications of non-English domain names in this field, see Wilson, “Internationalised Domain Names: Problems and Opportunities” (2004), 10(7) C.T.L.R. 174, and Pastukhov, O., "Internationalised Domain Names: the window of opportunity for cybersquatters” (2006), 4 Intellectual Property Quarterly 423.

133 E.g. Informa Law Resolving "WHOIS: online trade mark enforcement and the right to know” (2003), 162 T.W. 18 commenting on WHOIS and EC Directive 2002/58 (the "Privacy and Electronic Communications Directive”).

${ }^{134}$ Eg CircleID, Wall Street Journal Article on WHOIS Privacy (Apr. 27, 2006):

$<$ http://www.circleid.com/posts/wall_street_journal_whois_privacy/>

${ }^{135}$ ICANN, Final Task Force Report on Whois Services (2007):

$<$ http://www.icann.org/announcements/announcement-16mar07.htm> 


\subsection{UDRP and Internet Governance}

It has been argued that the United States exerts too much influence on ICANN, and ICANN on the internet. For example, Yu discusses some of the issues surrounding ccTLDs and ICANN. ${ }^{136}$ Many would like to see a more democratic structure of internet governance. The Geneva meeting of World Summit on the Information Society (WSIS) did not reach a consensus. ${ }^{137}$ The Working Group on Internet Governance ${ }^{138}$ was established by the UN in 2004. The issue dominated the prelude to and comment on the Tunis Meeting ${ }^{139}$ of WSIS in 2005. The key question was how, if at all, to impose a more democratic structure and how this could work in practice. There was significant divergence of national views, and a compromise only reached just before the Tunis Meeting. ${ }^{140}$ As a result, the Internet Governance Forum, referred to above, was established to take matters forward. ${ }^{141}$ This met in Athens in 2006, where the UDRP and its impact were considered. ${ }^{142}$ A further meeting will be held in Rio de Janeiro in 2007.

\subsection{Further activities}

The inclusion of the UDRP into FTAs could be seen as an attempt by the United States to strengthen the hand of ICANN in matters of governance of the domain name system, with potentially wider implications.

Research carried out for this project revealed little academic analysis about the inclusion of UDRP standards within these treaties. Possible areas to be further pursued are:

- the interaction between individual parties' domestic legal remedies and the availability of court action alongside a domain name dispute - particularly the potential for review via a declaratory judgment action of a dispute by a losing registrant; ${ }^{143}$

- the possibility of improving any perceived shortcomings with the UDRP within the context of complying with the 'principles' standard outlined in the FTAs;

\footnotetext{
${ }^{136}$ Yu, P., "The Never-ending ccTLD Story", in: Schlesinger Wass, E. (ed), Addressing the World: National Identity and Internet Country Code Domains (2003).

${ }^{137}$ WSIS Geneva Declaration of Principles and Plan of Action:

<http://www.itu.int/wsis/documents/doc_multi.asp?lang=en\&id=1161|1160>; See also McCarthy, K., "Internet Showdown Side-Stepped in Geneva” (2003), The Register:

<http://www.theregister.co.uk/2003/12/08/internet_showdown_sidestepped_in_geneva/>

${ }^{138}$ Working Group on Internet Governance: <http://www.wgig.org/>

${ }^{139}$ WSIS, Second Phase: Tunis Documents: <http://www.itu.int/wsis/documents/index2.html>

${ }^{140}$ WSIS Tunis Agenda for the Information Society: <http://www.itu.int/wsis/docs2/tunis/off/6rev1.html>. See also McCarthy, K., "Read the Letter that Won the Internet Governance Battle” (2005), The Register: <http://www.theregister.co.uk/2005/12/02/rice_eu_letter/>

${ }^{141}$ Internet Governance Forum: <http://www.intgovforum.org/>

${ }^{142}$ See IP-Watch: <http://www.ip-watch.org/weblog/index.php?p=447\&res=1024\&print=0; http://igf2006.info/workshops/legal-aspects>

${ }^{143}$ C.f. Cyberbritain UK Ltd v Nominet UK Ltd (2005)(QBD) (unreported), See: <http://www.outlaw.com/page-5979>
} 
- how implementation of UDRP-based policies affect e-commerce in the region. Importantly, do the new policies help or hinder new internet-based businesses?

- the impact of internet governance debates on the UDRP and for DR-CAFTA countries; ${ }^{144}$

- the contribution of FTA entrenchment of the UDRP on new forms of dispute resolution;

- human rights aspects of the policies, especially in regards to free speech issues; and

- $\quad$ analysing just what is required by the term 'principles' in DR-CAFTA.

\subsection{Copyright law}

As mentioned above, the DR-CAFTA agreement contains TRIPS plus copyright standards. IT-based businesses often are producers and movers of copyright content, and so these new provisions could potentially play very heavily into their business models. A review of the impact of the individual provisions in national law would be outside the scope of this project, but we have selected several provisions in the agreement that would be of some interest. The DMCA related provisions have been considered above.

- Article 15.5.4 requires that the copyright term for rights that are to be based on the life of a natural person, are set at life plus 70 years;

- $\quad$ article 15.5.2 calls for a 'making available' right; and

- article 15.5.1 requires a reproduction right, with full applicability to 'temporary storage in electronic form'.

DR-CAFTA also addresses enforcement. Parties are required in article 15.11.6 to have civil judicial procedures concerning the enforcement of 'any intellectual property right', which includes copyright. These civil judicial procedures must include the possibility of monetary damages claims (article 15.11.7) and orders for the seizure of the infringing goods (article 15.11.10). At the end of the suit, the prevailing party will normally also be awarded costs and attorney's fees (article 15.11.9).

Of particular concern however is a provision in DR-CAFTA requiring statutory damages for copyright infringement. Article 15.11 .8 requires that:

"In civil judicial proceedings, each Party shall, at least with respect to civil judicial proceedings concerning copyright or related rights infringement and trademark counterfeiting, establish or maintain pre-established damages as an alternative to actual damages. Such pre- established damages shall be set out in domestic law and determined by the judicial authorities in an amount sufficient to compensate the right holder for the harm caused by the infringement and constitute a deterrent to future infringements”

${ }^{144}$ Westlaw searches of udrp /p "free trade" "regional trade” produced 3 hits. 
The possibility for a copyright owner to choose statutory damages provisions could be quite a radical change in the copyright enforcement structures in DR-CAFTA countries. Not having to prove actual damages in copyright infringement cases could significantly ease the burden of going to court to ask for damages. In the United States, where statutory damages for copyright infringement have been in place, the Recording Industry Association of America has used these provisions to file thousands of lawsuits against individuals. ${ }^{145}$ The statutory damages provisions give a powerful incentive to settle these cases early on in the process. ${ }^{146}$ The introduction of these damages into other legal systems could have a profound effect, and further study on the judicial reforms as related to copyright enforcement in the individual parties would be needed.

\subsection{Anti-circumvention measures}

Digital Rights Management (DRM), is a very broad term that encompasses all sorts of technical ways to manage information, this may include tracking use, restricting access, or simply keeping count of usage of the work. ${ }^{147}$ These technologies can be used to restrict unauthorised access to works subject to copyright, but such technical protections are subject to circumvention by hackers and technology experts. Copyright owners therefore have lobbied for the regulation, criminalisation and sanction of the act of circumventing technical protection.

Because technical protection measures (TPMs) can be circumvented (sometimes with extreme ease), one priority of the international community has been to legally protect TPMs by prohibiting all sorts of unauthorised circumvention practices. The main international agreement dealing with circumvention of technological protection measures is the WIPO Copyright Treaty (WCT). The intention of the treaty is to request member states to restrict and provide remedies against the breaking of TPMs. Art. 11 says:

"Contracting Parties shall provide adequate legal protection and effective legal remedies against the circumvention of effective technological measures that are used by authors in connection with the exercise of their rights under this Treaty or the Berne Convention and that restrict acts, in respect of their works, which are not authorized by the authors concerned or permitted by law.”

The agreement has been implemented into national legislation in several countries with a wide range of languages and interpretations. Section 1201(1) of the US Digital Millennium Copyright Act (DMCA) states, "No person shall circumvent a technological

\footnotetext{
${ }^{145}$ Boag, J., "The Battle of Piracy versus Privacy: How the Recording Industry Association of America (RIAA) is Using the Digital Millennium Copyright Act (DMCA) as its Weapon Against Internet Users' Privacy Rights” (2004), 41 California Western Law Review 241.

${ }^{146}$ Barker, J.C., "Grossly Excessive Penalties in the Battle against Illegal File-Sharing: the Troubling Effects of Aggregating Minimum Statutory Damages for Copyright Infringement" (2004), 83 Texas Law Review 525.

${ }^{147}$ For more about the general concepts, see: Yu (2006), supra. 16.; Dusollier, S., "Electrifying the Fence: The Legal Protection of Technological Measures for Protecting Copyright" (1999), 21(6) EIPR 285.
} 
protection measure that effectively controls access to a work protected under this title." it also sets civil and criminal sanctions in the case of wilful circumvention for commercial gain. In Europe, the WCT has been implemented by the European Copyright Directive. ${ }^{148}$ Art. 6(1) states, "Member States shall provide adequate legal protection against the circumvention of any effective technological measures, which the person concerned carries out in the knowledge, or with reasonable grounds to know, that he or she is pursuing that objective.”

As mentioned above, most DR-CAFTA states have implemented TPM protection in one form or another in accordance to their obligations as WCT signatories. Costa Rica for example has implemented criminal sanctions of up to three years for those who remove technical protection measures and even digital rights management systems. ${ }^{149}$

DR-CAFTA imposes obligations with regards to anti-circumvention measures that go beyond WCT requirements. Art 15.5.7(a) reads:

"In order to provide adequate legal protection and effective legal remedies against the circumvention of effective technological measures that authors, performers, and producers of phonograms use in connection with the exercise of their rights and that restrict unauthorized acts in respect of their works, performances, and phonograms, each Party shall provide that any person who:

(i) circumvents without authority any effective technological measure that controls access to a protected work, performance, phonogram, or other subject matter; or (ii) manufactures, imports, distributes, offers to the public, provides, or otherwise traffics in devices, products, or components, or offers to the public or provides services, that:

(A) are promoted, advertised, or marketed for the purpose of circumvention of any effective technological measure; or

(B) have only a limited commercially significant purpose or use other than to circumvent any effective technological measure; or

(C) are primarily designed, produced, or performed for the purpose of enabling or facilitating the circumvention of any effective technological measure,

shall be liable and subject to the remedies provided for in Article 15.11.14. Each Party shall provide for criminal procedures and penalties to be applied when any person, other than a nonprofit library, archive, educational institution, or public non-commercial broadcasting entity, is found to have engaged willfully and for purposes of commercial advantage or private financial gain in any of the foregoing activities."

\footnotetext{
${ }^{148}$ Directive 2001/29/EC of the European Parliament and of the Council of 22 May 2001 on the harmonisation of certain aspects of copyright and related rights in the information society, supra. 77. 149 Arts 62 and 63, Ley de Procedimientos de Observancia de los Derechos de Propiedad Intelectual, número 8039 de 5 de octubre del 2000.
} 
Some critics of FTAs in general have complained about these types of provisions, as they are seen as an exportation of the DMCA's application of the WCT, and an excessive criminalization of practices that go beyond the minimalist international harmonization system exemplified by the WCT. ${ }^{150}$ Section 1201 of the DMCA, which implements the WCT, is seen as the maximalist end of the spectrum in anti-circumvention measures. The export of the draconian language encountered in s. 1201 would provide no foreseeable benefit to developing economies other than to assist in locking content from developed nations. Garclick, for example, comments:

"While consideration of proposals for recognizing developing country concerns in a world of technological locks is worthwhile, overall, the main challenge which $\S 1201$ presents for developing countries is the fact that it is being established as the default international minimum standard, without broad-based, international consultation. By shifting the debate about the suitability of such a maximalist model from the international, multilateral to the bilateral agenda, developing countries seem less able to resist its adoption. When part of a multiparty negotiation, it seems that developing countries are able to negotiate sufficient compromise on strong copyright protections within which their domestic information policy objectives can be realized.”151

Another criticism is that the inclusion of the agreement into regional trade agreements "give teeth" to anti-circumvention provisions, as the WCT does not encompass enforcement and dispute settlement mechanisms for member states which are not in compliance, while FTAs do. ${ }^{152}$

Are there any benefits for developing countries from the adoption of strong anticircumvention measures? It could be argued that allowing for better protection of DRMs may serve as encouragement for local markets and authors to impose their own technical fences around their works. However, there seems to be no visible benefit to criminalise practices which may not be relevant in countries with little connection to the Information Society, but this is a potential area of further research. A study into the application and enforcement of anti-circumvention legislation in DR-CAFTA countries would be most welcome.

${ }^{150}$ Chander, C., “Exporting DMCA Lockouts” (2006), 54 Cleveland State Law Review 205.

${ }^{151}$ Garlick, M.K., "Locking up the Bridge on the Digital Divide-a Consideration of the Global Impact of the U S Anti-Circumvention Measures for the Participation of Developing Countries in the Digital Economy" (2004), 20(4) Santa Clara Computer and High-Technology Law Journal 941. ${ }^{152}$ Chander, supra. 140, p.213. 


\subsection{Competition law}

\subsection{DR-CAFTA}

The DR-CAFTA does not address competition or antitrust law. ${ }^{153}$ Other FTAs to which the US is a party have, however, included competition chapters. ${ }^{154}$ As is noted below, this is a potentially important omission.

\subsection{International competition regulation}

One reason for this might be the lack of international consensus as to what competition laws should comprise in terms of basic principles. Attempts to progress this, notably to include competition in the WTO Doha Development Round failed, ${ }^{155}$ and international efforts now focus on collaboration. ${ }^{156}$ Where agreement exists, (for example there is significant consensus between the competition laws of the EC and the United States), the central role played by economic and market considerations means that different approaches can be adopted in practice. ${ }^{157}$

\subsection{Central American competition regulation}

In DR-CAFTA countries other than the US, competition law is undeveloped. Only Costa Rica has a national competition authority, although Costa Rica, Guatemala, Nicaragua and the Dominican Republic have some competition legislation. There have also been recent initiatives to develop competition law in the region. ${ }^{158}$

In the light of these factors, it is perhaps understandable that DR-CAFTA does not deal generally with competition principles (see below in respect of Telecommunications). However, competition law can have an important impact on IT-based businesses:

\footnotetext{
${ }^{153}$ Although there are some references to competition, see eg DR-CAFTA Chapter 9 and Chapter 1, paragraph 1.2(c), regarding the objective of fair competition.

${ }^{154}$ E.g. Australia-US FTA Chapter 14, Chile-US FTA Chapter 16As to Chile, SICE has a guide comparing it to CAFTA, with a chapter on competition:

<http://2005.sice.oas.org/TPCStudies/USCAFTAChl_e/CompStudy16.htm>

${ }^{155}$ Marsden, P., A Competition Policy for the WTO (2003), pp.15-66; For resources and overview see WTO, Interaction between Trade and Competition Policy:

$<$ http://www.wto.org/english/tratop_e/comp_e/comp_e.htm>; See also Doha Ministerial Declaration WT/MIN(01)/DEC/1 paras 23-5:

<http://www.wto.org/english/thewto_e/minist_e/min01_e/mindecl_e.htm\#interaction>; See also Decision of General Council 1 August 2004 WT/L/579:

<http://www.wto.org/english/tratop_e/dda_e/draft_text_gc_dg_31july04_e.htm>

${ }^{156}$ International Competition Network:

<http://www.internationalcompetitionnetwork.org/index.php/en/about-icn>

${ }^{157}$ See Marsden, supra. 145.

158 These have been policy based (see ECLAC, Strengthening Competition in the Central American Isthmus $<$ http://www.eclac.cl/mexico/competencia/proyecto/indexing.htm\#>) and also at institutional level -

FTAA, Organization of American States. These have not proceeded. See resource list:

<http://www.llrx.com/features/newhorizons.htm\#Western\%20Hemisphere>
} 
consider recent regulatory intervention in the EC and US in respect of Microsoft, ${ }^{159}$ and concern at the competitive implications of network and standardised industries, important in IT fields. ${ }^{160}$ More broadly, as recognised in the ongoing regional and international initiatives, competition can be a valuable contributor to a developing economy, although it may raise controversial questions of the role of state regulation, markets and private enterprise.

\subsection{Further activities}

The continuing freedom of DR-CAFTA countries to choose, or not choose, to introduce their own competition laws means there will continue to be regional uncertainty. It remains to be seen whether this is beneficial for DR-CAFTA countries in respect of the development of IT based business. To the extent that this project pursues future economic analysis, the relevance of competition and its possible contribution could be explored.

\subsection{Telecommunications}

Telecommunications deregulation is a complicated area of the law, to say the least. Since at least the 1940's, the overall approach by governments has been that in the case of telephony, monopolies were beneficial. This mainly stems from economic arguments concerning the inefficiencies involved in having more than one company building up the physical infrastructure (telephone lines, etc) to connect people to the system. This approach led to state-owned telephone utilities, such as BT or de-facto government sponsored monopolies, such as AT\&T in the US.

\subsection{Telecom deregulation in DR-CAFTA}

From about the late 1970 's, and increasingly in the 1980's, the telecoms market has been facing greater deregulation. DR-CAFTA, like other FTAs that the US has been signing, ${ }^{161}$ contains provisions requiring the deregulation of the telecoms markets of members. These measures are largely tied to how the physical structure, the architecture of the systems, is used. Generally, these are rules on access to equipment and

\footnotetext{
${ }^{159}$ Commission Decision of 24/03/04 relating to a proceeding under Article 82 of the EC Treaty (Case COMP/C-3/37.729 Microsoft), available via:

$<$ http://ec.europa.eu/comm/competition/antitrust/cases/decisions/37792/en.pdf>; and US v. Microsoft Corp: <http://www.usdoj.gov/atr/cases/ms_index.htm>

${ }^{160}$ See eg Lemley, M.A. \& McGowan May, D., "Legal Implications of Network Economic Effects” (1998), 86 Calif. L. Rev. 479; Lemley, M.A., "Standardizing Government Standard-Setting Policy for Electronic Commerce” (1999), 14 Berkeley Tech. L.J. 745; See also International Committee for Information Technology Standards: <http://www.incits.org/>; c.f. Dynamic Coalition on Open Standards: <http://www.cptech.org/a2k/igf/athens110206/key_docs.html>; For a different perspective on standards which could also be of future relevance in the IT field see Chapter 8 DR-CAFTA, Technical Barriers to Trade, which addresses standards.

${ }^{161}$ See list from USTR: <http://ustr.gov/Trade_Sectors/Telecom-Ecommerce/Telecom_FTA_Chapters/Section_Index.html>
} 
transparency of agreements, but also include consumer protection measures in order to prevent anti-competitive practices. They include provisions on:

- number portability: article 13.3.3 - this is the ability for consumers to switch carriers while retaining their phone number;

- dialling parity: article 13.3.4 - equal dialling access, such as the same number of digits for each carrier and equal access to blocks of numbers and timeliness of connection;

- unbundling of services: article 13.4.4 - the separation of 'network elements' in terms of rates and access;

- leased circuits: article 13.4.6 - the requirement to lease use of its network to other suppliers on a non-discriminatory basis;

- collocation: article 13.4.7 - the ability to place equipment needed for interconnection at the same physical location as other equipment;

- rights-of-way: article 13.4.8 - the right to use the same 'poles, ducts, conduits and rights-of-way' as the major telecommunications suppliers on nondiscriminatory terms; and

- independence of the regulatory body: article 13.7 - provides for neutrality and equal treatment by the regulatory body, including requirements that the regulating body for telecommunications cannot have a financial interest or have an operating role in the companies it regulates.

How these and the other requirements of the telecommunications chapter translate into practice into the individual jurisdictions is obviously a question highly related to the relevant legal system and their public telecommunications governance structure. But if the end result of these requirements is to decrease the 'digital divide' by providing better quality and lower cost services, especially internet services, this will have an exponential effect on IT-based businesses in the region in addition to human rights benefits. In addition, deregulation of the wireless communications market can have profound effect on areas such as 'm-commerce' - transactions via mobile telephone services, and open up the sector to greater competition.

\subsection{Leapfrogging}

Alternative physical infrastructures will also come into play when examining the telecoms market in the region. This brings in the idea of 'leapfrogging', where a new market gets to use the latest communications technology, where other markets may still be stuck using older forms. One of the most cited examples of leapfrogging can be found in cellular phone markets in emergent economies, where a look at the figures indicate that developing countries that never had time to developed their wired telecommunications infrastructures are now moving into wireless technologies at much lower costs. ${ }^{162}$ The phenomenon seems to be replicated not only in developing countries, but also in

${ }^{162}$ Fink, C., \& Kenny, C.J., "W(h)ither the digital divide?" 5(6) Info 15 (2003). 
emerging economies, which would seem to indicate that we are presented with a global characteristic of the Information Society. ${ }^{163}$

Leapfrogging is made possible by a growing number of user-friendly and low-cost technologies that provide inhabitants increasingly affordable solutions to access telecommunications. For example, wireless mesh networking could offer alternatives for high-quality broadband access using a low cost infrastructure that is generally not subject to the same level of regulation as the standard telecoms industry. ${ }^{164}$ VoIP, personal satellite services, other wireless technologies all feed into the decreasing dominance of the traditional telecom industry - and thus the regulatory structures used to control it. ${ }^{165}$

\subsubsection{Statistics}

The statistics below are merely provided to get some idea of the numbers behind issues surrounding the digital divide in DR-CAFTA countries. Note that the numbers are from 2004, and undoubtedly the rates have dramatically increased since this time for some member countries.

\begin{tabular}{|l|l|l|}
\hline & $\begin{array}{l}\text { Fixed line and mobile } \\
\text { phone subscribers (per } \\
1,000 \text { people) in 2004. }\end{array}$ & $\begin{array}{l}\text { Internet users per } \\
1,000 \text { people in 2004. }\end{array}$ \\
\hline Costa Rica & 532.9 & 235.1 \\
\hline El Salvador & 402.3 & 86.9 \\
\hline Dominican Republic & 395.8 & 91.2 \\
\hline Guatemala & 349.8 & 61.5 \\
\hline Honduras & 153.0 & 31.5 \\
\hline Nicaragua & 177.3 & 23.3 \\
\hline
\end{tabular}

163 Wei and Kolko, "Studying mobile phone use in context: cultural, political, and economic dimensions of mobile phone use”, Proceedings of the Professional Communication Conference (2005), pp.205- 212

${ }^{164}$ Akyildiz, I.F. \& Wang, X., "A survey on wireless mesh networks” (2005), 43(9) Communications Magazine 23.

${ }^{165}$ Guadamuz, A. “The Digital Divide: It's the Content, Stupid!” (2005) 3-4 Computer and Telecommunications Law Review, 73-77 \& 113-118. 


\begin{tabular}{|l|l|l|}
\hline United States & $1,222.7$ & 630.0 \\
\hline
\end{tabular}

\subsection{Conclusion}

Throughout this report, we have identified areas of potential further study. In the conclusion we revisit several of these threads to weave a plan for further enquiry. One of the main themes is the central role of ISPs - their liability or immunity is addressed directly, the sites that they administer will more and more be subject to the UDRP, and their number and service levels directly influence (and in turn are influenced by) the growth of e-commerce within the region.

As such, we propose concentrating on quantitative and qualitative study of ISPs within the region. This would by necessity involve further comparative analysis of the use of DMCA intermediary liability standards within the region - as identified above little work exists in this area. Together with a legal analysis of the liability for providers, interviews with ISPs could deliver a picture of the use of certain provisions within DR-CAFTA, most notably the notice and take down process.

After connections are in place with the initial studies of the narrow area of ISP liability, we can build on these relationships and expertise to work on further complementary areas, such as privacy concerns with the WHOIS systems and domain name dispute resolution under the 'UDRP principles' requirements. In addition, ISPs can provide an interesting case study for the introduction of pre-established damages in copyright, and further work in this area is already planned by one team member.

\subsection{Workshop}

One of the main themes that has arisen out of the research for this project is a need for academics and lawyers from both the trade law and IT law field, from a range of jurisdictions and perspectives, to collaborate and share ideas. It might also be helpful for discussions to include economists, political scientists and international relationships experts. This should enable outputs and proposals more grounded in both legal theory and practical reality.

To begin this process, we propose holding a workshop where these groups can meet and discuss issues surrounding IT industries and trade.

Though the focus of this report has been the DR-CAFTA agreement, this meeting should focus on broader issues of free trade and IT, and also lessons which can be learned by those implementing and studying DR-CAFTA by those with experience in respect of other FTAs. 